OPEN ACCESS

Edited by:

Vassiliki Papaevangelou,

National and Kapodistrian University

of Athens, Greece

Reviewed by:

Laura Ferreras-Antolín,

NHS England, United Kingdom

Rinawati Rohsiswatmo, RSUPN Dr. Cipto

Mangunkusumo, Indonesia

${ }^{*}$ Correspondence: Sallie R. Perma

sallie.permar@duke.edu

Specialty section

This article was submitted to Pediatric Infectious Diseases,

a section of the journal

Frontiers in Pediatrics

Received: 17 March 2020

Accepted: 04 August 2020

Published: 15 December 2020

Citation:

Singh T, Otero CE, Li K, Valencia SM,

Nelson AN and Permar SR (2020)

Vaccines for Perinatal and Congenital

Infections-How Close Are We?

Front. Pediatr. 8:569

doi: $10.3389 /$ fped.2020.00569

\section{Vaccines for Perinatal and Congenital Infections-How Close Are We?}

\author{
Tulika Singh ${ }^{1,2}$, Claire E. Otero ${ }^{1}$, Katherine Li $^{1}$, Sarah M. Valencia ${ }^{1}$, Ashley N. Nelson ${ }^{1}$ and \\ Sallie R. Permar ${ }^{1,2 *}$ \\ ${ }^{1}$ Duke University Medical Center, Duke Human Vaccine Institute, Durham, NC, United States, ${ }^{2}$ Department of Molecular \\ Genetics and Microbiology, Duke University, Durham, NC, United States
}

Congenital and perinatal infections are transmitted from mother to infant during pregnancy across the placenta or during delivery. These infections not only cause pregnancy complications and still birth, but also result in an array of pediatric morbidities caused by physical deformities, neurodevelopmental delays, and impaired vision, mobility and hearing. Due to the burden of these conditions, congenital and perinatal infections may result in lifelong disability and profoundly impact an individual's ability to live to their fullest capacity. While there are vaccines to prevent congenital and perinatal rubella, varicella, and hepatitis B infections, many more are currently in development at various stages of progress. The spectrum of our efforts to understand and address these infections includes observational studies of natural history of disease, epidemiological evaluation of risk factors, immunogen design, preclinical research of protective immunity in animal models, and evaluation of promising candidates in vaccine trials. In this review we summarize this progress in vaccine development research for Cytomegalovirus, Group B Streptococcus, Herpes simplex virus, Human Immunodeficiency Virus, Toxoplasma, Syphilis, and Zika virus congenital and perinatal infections. We then synthesize this evidence to examine how close we are to developing a vaccine for these infections, and highlight areas where research is still needed.

Keywords: vaccines, immunology and infectious diseases, congenital infections, perinatal infections, child health

\section{INTRODUCTION}

Congenital and perinatal infections are caused by pathogens that infect a pregnant woman and can be passed to the fetus during pregnancy by infecting and crossing the placental barrier or infecting the newborn during delivery in the birth canal. By definition, these infections are different from neonatal and childhood diseases that are contracted after birth. When passed to the newborn, these infections can lead to developmental defects, physical deformities, and lifelong disability. Maternal infection of the placenta may also lead to complications in pregnancy such as intrauterine growth restriction, miscarriage, and stillbirth. Given immunological and biological alterations that occur in pregnancy, the course of infection and immunity can be more severe in pregnancy, which dually impacts maternal health and ability to recover. Moreover, pregnancy is a time during which many treatments may be contraindicated, which limits options upon diagnosis. In these settings, vaccines are a valuable tool to prevent congenital infections. While there are three licensed vaccines to prevent congenital infections, many more are in development. 
In this review, we outline key strategies for vaccine design to prevent congenital and perinatal infection and highlight the three licensed vaccines. Then we detail vaccine development efforts, protective immunity, and design considerations for congenitally transmitted pathogens that threaten the health of newborns: Cytomegalovirus, Group B Streptococcus, Herpes simplex virus, Human immunodeficiency virus, Toxoplasma, Syphilis, and Zika virus.

\section{STRATEGIES FOR VACCINES TO PREVENT CONGENITAL INFECTIONS}

There are two broad strategies for immunization to prevent congenital infections: (1) vaccinating women prior to pregnancy to generate protective maternal immunity; (2) providing passive or active immunization during pregnancy to boost immunity and prevent congenital transmissions with possible exposures later in pregnancy or at delivery. Vaccines against congenital infections depend on eliciting protective immune responses against the congenitally transmitted pathogen, that are sustained at a protective level at least through pregnancy. A protective threshold of antibodies or immune responses is ideally required prior to pregnancy to prevent maternal infection, and thereby prevent congenital transmission. Therefore, defining immune correlates is critical to the design and development of vaccines to prevent congenital infections.

For vaccinations delivered before pregnancy, high rates of seroconversion across populations and long-lasting immunity are critical features. As with the Rubella vaccine provided in childhood, vaccine-elicited immunity must protect diverse populations of women during a wide range of ages when they may be pregnant. As most pregnancies are unplanned, the optimal vaccine to prevent congenital infections must be administered well before the earliest age groups for women's reproductive age.

Importantly, active and passive vaccine-based strategies work together with other measures that support in preventing and controlling congenital infection. Infant health can also be improved if a worse secondary disease can be prevented, after the congenital infection or exposure. For example, with perinatal Hepatitis B exposure, a birth dose of vaccine and immunoglobulin protects the newborn from liver disease over their lifetime. Administration of drugs after birth is a secondary prevention measure intended to reduce morbidity and mortality by preventing disease progression after exposure. Moreover, there are complementary measures to reduce risk of transmission and severity of disease such as maternal or neonatal treatments, and public health measures to reduce exposure during pregnancy by limiting population-wide transmission. Specifically, these include programs to promote condom use or control mosquitoes, depending on the route of transmission. Though there are guidelines to screen for disease early in pregnancy, implementation of TORCH pathogen screening and standard of care vary widely. In low resource settings in particular, limited antenatal care access results in missed opportunities for prevention of congenital infections $(1,2)$. Systemic structural barriers and failures of prevention and treatment strategies indicate a need to complement interventions with vaccines to prevent congenital diseases.

There are three licensed vaccines for prevention of congenital infections: Rubella, Hepatitis B, and Varicella, which all use the strategy of immunization in childhood to elicit long lasting immunity prior to pregnancy, as well as provide passive immunization of the infant during pregnancy. These vaccines serve as successful examples that inspire and guide the many more in development.

\section{Rubella}

Rubella infection in pregnant women, especially during the first trimester, can lead to serious fetal consequences including spontaneous abortion, infant death, and congenital rubella syndrome (CRS). CRS describes a range of birth defects including hearing impairment, cataracts, congenital heart disease, and neurological impairment (3). To prevent CRS, the measles mumps and rubella combined MMR vaccine is recommended as a two-dose series after 12 months of age (4). As a liveattenuated virus vaccine, the MMR vaccine is contraindicated for administration during pregnancy (4). In the pre-vaccine era, the US epidemic of 1964-65 resulted in 6,250 spontaneous abortions, 2,100 infant deaths at birth or soon after, and CRS in 20,000 infants, leading to deafness, blindness, and mental impairment (5). More recently, lack of high levels of vaccine coverage and concern for waning of immunity has led to prenatal screening of women and recommendations of immunization at least 1 month prior to conception in unvaccinated women who desire to become pregnant (6). The WHO regions of the Americas and Europe have achieved CRS elimination, whereas globally, vaccine coverage is suboptimal and $31 \%$ of countries have yet to introduce the vaccine and benefit from this protection (7).

\section{Hepatitis B}

The vaccine for Hepatitis B virus (HBV) is offered as a threedose vaccine starting at birth and has achieved $84 \%$ global coverage as of $2015(8,9)$. Chronically infected pregnant women may transfer the virus to their infant at delivery. Thus, HBV screening is recommended in pregnancy (8). For mothers with an active infection or immunity below the correlate of protection a combination of infant immunoglobulin prophylaxis, active vaccine and antiviral therapy is recommended (8). Since earlier infection in life leads to a greater likelihood of chronic liver disease, cancer, and death, intervention at birth after perinatal exposure is crucial. A birth dose of the vaccine reduces the risk for neonatal infection by $72 \%$ and up to $90 \%$ when combined with HBV immunoglobulin post-exposure prophylaxis (10, 11). If left untreated, 70-90\% of perinatally infected infants develop chronic infection by 6 months (12). While passive immunoprophylaxis provides temporary protection, the vaccine offers longterm protection (13).

\section{Varicella}

Varicella zoster-virus is the causative agent of chickenpox and shingles. The live-attenuated VZV vaccine is recommended for infants older than 12 months and is intended to reduce morbidity and mortality from childhood infection (14). The vaccine elicits 
lifelong protective immunity (14). Historically, the virus would infect nearly everyone by middle ages, with greatest incidence of disease in elementary school years with low rates of maternal infection (15). Rarely, maternal infection during pregnancy can lead to congenital varicella syndrome, which is characterized by limb hypoplasia, skin abnormalities, encephalitis, neurological impairment, and low birth weight (16). Prenatal assessment of women for varicella immunity and vaccination at least 1 month prior to conception is recommended, though this is not regularly performed or feasible in the event of unplanned pregnancies (14). If a pregnant woman lacks immunity, is exposed to the pathogen, or becomes infected, VariZIG, a human VZV immunoglobulin, is offered as post-exposure prophylaxis for the mother and pre-term neonate depending on exposure risk (17). VariZIG is a passive immunization strategy that is most effective within 96 hours of exposure but is also approved within 10 days of infection $(17,18)$. Thus, far, most countries have not adopted the childhood varicella vaccine, due to cost and concerns of incomplete coverage leading to greater risk of disease in pregnancy as compared to childhood (19).

\section{SPECIAL CONSIDERATIONS FOR DESIGN OF MATERNAL VACCINES}

Many maternal vaccination strategies to date are aimed at providing fetal and infant immunity to these pathogens by transfer of protective antibodies (20-23). Transfer of IgG across the placenta into the fetal compartment during pregnancy may have a role in preventing congenital and perinatal infections (24). Antibodies of the IgG isotype begin to cross the placenta around gestational week 13 when the neonatal Fc receptor, FcRn, starts to be expressed on the placenta $(25,26)$. Many qualities of the IgG antibodies may contribute to the efficiency of transplacental transfer, including IgG subclass, antibody avidity, and gestational stage (27-29). Placental transfer of antibodies is most efficient for the IgG1 subclass, followed by IgG4, IgG3, and IgG2 with decreasing efficiencies (25). This is due to IgG glycosylation and varying binding affinities of the Fc region of the IgG subclasses to the FcRn $(30,31)$. Since IgG1 are elicited more in response to proteinaceous antigens than polysaccharide antigens, vaccine antigens can be designed to incorporate proteinaceous elements of the pathogen.

However, high titers of placentally transferred antigen-specific IgG in the infant may also reduce the magnitude of the infant's de novo immune responses to vaccines containing that antigen (32-34). This is best studied in the context of the measles vaccine, which is a live-attenuated replicating vaccine. While morbidity and mortality are reduced in children vaccinated against measles in the presence of maternal antibodies, protective neutralizing antibody responses are not established until booster doses when maternal antibody has waned $(35,36)$. This phenomenon, known as maternal antibody interference, and has been documented with many types of vaccines, including liveattenuated, inactivated, and protein or polysaccharide (subunit or conjugate) vaccines (37-49). Thus, vaccine design and timing must be guided by the requirements for IgG transfer to optimize prevention of congenital infection, as well as requirements for neonatal immunity prior to the age of greatest risk of exposure.

\section{PROGRESS IN VACCINE DEVELOPMENT FOR PERINATAL AND CONGENITAL INFECTIONS}

For each pathogen, we detail transmission route, disease burden, evidence for current clinical guidance, key features of protective immunity, and vaccine design considerations. These crucial aspects are synthesized to evaluate progress and gaps remaining toward vaccine development.

\section{CYTOMEGALOVIRUS (CMV)}

In utero transmission of $\mathrm{CMV}$ is the most common congenital viral infection as $\sim 1$ in every 200 babies, or 30,000 infants annually, are born with congenital CMV (cCMV) in the US (50-54). While CMV infection is typically asymptomatic in healthy adults, including pregnant women, the major challenge for prevention of cCMV stems from viral latency, which allows CMV to persist and reactivate over a lifetime (55-57). In the most severe cases, vertical transmission of $\mathrm{CMV}$ can lead to fetal loss; more commonly, cCMV infection can cause severe defects and sequelae in the neonate, including hearing loss and developmental delays and which occur in an estimated $20 \%$ of cCMV-positive infants $(53,58,59)$. This leads to lifelong disability. The risk of placental CMV transmission is greater for seronegative women who have primary infection during pregnancy $(30-50 \%)$ than for chronically infected women experiencing secondary infection or viral reactivation (1-4\%), indicating that the maternal adaptive immune response can be protective (50, 53, 60-63). However, reactivation of latent CMV or re-infection in seropositive pregnant women accounts for the majority of congenital infections because $60-90 \%$ of the global population is seropositive for CMV, with higher prevalence in developing countries (64-66).

CMV is shed in body fluids such as urine, saliva, breast milk, and semen and is typically transmitted via physical and mucosal contact with such fluids (50, 67-71). Consequently, direct contact, breast feeding, organ transplants, and blood transfusions are the possible routes of transfer in addition to congenital transmission from mother to the fetus. CMV can be transmitted vertically in any trimester of pregnancy, indicating that the target population for a vaccine to prevent cCMV would be women of child-bearing age prior to conception (72-78). The risk of transmission is greatest in the third trimester, but the risk of the child developing sequelae is greatest when transmission occurs early in gestation $(61,74,79)$. People who spend a significant amount of time around young children, including childcare workers, teachers, and parents, are especially at risk. In high-income countries, maternal exposure through toddlers at daycare is a key route of exposure to the virus for pregnant women. As of now, there is no licensed vaccine for prevention of cCMV, despite over 40 years of research. The development of a CMV vaccine has been designated as a top priority by 
the National Academy of Medicine, and preclinical and clinical research efforts are on-going (80).

\section{Current Guidance}

There is no clinical guidance to test for maternal CMV infection in the prenatal period. Because CMV infection in most adults is asymptomatic, cCMV infection during pregnancy is typically identified by abnormal fetal ultrasound findings, such as echogenic fetal bowel, cerebral ventriculomegaly, periventricular calcifications, and fetal growth restriction, which leads to maternal CMV testing $(63,77,81,82)$. Maternal infection is identified by detecting viral DNA via PCR in serum or urine or by assessing CMV-specific serum antibodies and avidity $(63,83)$. Congenital infection is determined via amniocentesis, generally only when maternal infection has been confirmed and after 21 weeks of gestation $(63,84-86)$. Testing for CMV at birth is becoming more commonplace, but traditionally, doctors will only order a CMV test if a baby shows multiple symptoms that can be associated with cCMV, such as low birth weight, jaundice, and/or microcephaly (50,67, 87-90). However, CMV testing is recommended for newborns with documented sensorineural hearing loss regardless of the presentation of other symptoms or sequelae (89).

Several studies highlight the safety of administering hyperimmune globulin (HIG) treatment in pregnancy and benefits such as controlling maternal viral load, lowering rates of congenital transmission, and reducing severity of neonatal infection. Though the evidence remains divided as to the value of this intervention: two observational studies, a case-control, and a non-randomized study reveal that HIG lowered rates of vertical transmission, whereas two follow-up randomized placebo-controlled trials did not confirm this finding (91-95). More recent studies indicate that high-dose HIG and maternal DNAemia independently predict congenital transmission, suggesting that multiple factors should be considered for prevention of cCMV by HIG (96).

Though treatment options are currently limited, there is guidance for preventing CMV infection during pregnancy, including limiting new sexual partnerships and, more importantly, exposure to young children and their various bodily fluids. Given that exposure to urine and saliva from toddlers is an important route of transmission, pregnant women frequently exposed to young children are encouraged to take personal precautions such as washing their hands often, especially after changing diapers, and avoiding sharing food, drinks, and eating utensils with young children (67, 97-99).

\section{Protective Immunity}

Animal models that have been employed to study placental CMV infection, include guinea pigs and non-human primates. Traditionally, the guinea pig model has been used to study cCMV infection because guinea pig CMV is capable of crossing the placenta in pregnant guinea pigs, while other small animals cannot model the placental viral transmission $(100,101)$. Preclinical vaccine candidates include vectored viral glycoproteins, glycoprotein $\mathrm{B}(\mathrm{gB})$ protein, the pentameric complex of CMV involved in cell entry, and combinations of surface proteins
(102). These candidates show promising results in the guinea pig animal model with respect to reduction of maternal viral load and improved fetal health (103-107). Recently, a pregnant rhesus macaque model of cCMV following primary infection during pregnancy was developed. Early studies using this model found that $\mathrm{CD} 4+\mathrm{T}$ cell depletion prior to challenge produces a consistent measurable phenotype of cCMV transmission (108, 109). In the absence of CD4+ T cells, passive infusion of potently neutralizing antibodies against rhesus macaque CMV (RhCMV) was protective against placental RhCMV transmission (110). This model promises to further our understanding of maternal protection against placental transmission of CMV as the rhesus macaque immune system better models that of humans and there is significant functional homology between the RhCMV and human $\operatorname{CMV}(109,111,112)$. Thus far, these studies indicate the importance of $\mathrm{CD} 4+\mathrm{T}$ cells in a protective maternal CMV immune response and the protective effect of humoral immunity $(108,110,113)$.

To date, the most effective CMV vaccine candidate tested in clinical trials is comprised of $\mathrm{gB}$, one of the glycoproteins responsible for viral entry into cells upon infection (114), with a MF59 squalene adjuvant. This is currently the only preventative platform against viral acquisition that has completed phase II clinical trials (115). This vaccine was tested in cohorts of post-partum women, adolescent girls, and transplant recipients, and resulted in a partial efficacy of $50 \%$ against CMV acquisition as well as successfully prevented viremia in transplant recipients (115-117). Studies that stem from these trials continue to inform the immune correlates associated with protection from acquisition. While CMV neutralizing antibodies have been implicated in reducing placental transmission in the context of primary infection during pregnancy $(103,110)$, CMV neutralization titers did not correlate with protection in the gB/MF59 vaccine trials (118-124). Rather, non-neutralizing antibody effector functions, such as antibody-dependent cellular phagocytosis, have recently been implicated in mediating protection in the $\mathrm{gB} / \mathrm{MF} 59$ vaccine trials, within the target population of adolescent girls and postpartum women (118, $124,125)$. This suggests that non-neutralizing antibody effector functions may be an important part of CMV immunity in addition to neutralizing antibody responses.

Another vaccine strategy has been to target $\mathrm{T}$ cell responses to viral proteins in order to mediate robust viral clearance from tissues. This is supported in the context of congenital infection by the finding that $\mathrm{CD} 4+\mathrm{T}$ cells are important for preventing placental transmission in the rhesus macaque model of primary infection during pregnancy (108). The focus of vaccine candidates tested in pre-clinical studies has been on pp65 and IE1, as they contain T cell epitopes present in many seropositive individuals (126-130). Pre-clinical studies using pp65 or homologs as the vaccine immunogen have yielded improved pregnancy outcomes, indicating that cellular immunity against tegument proteins can be protective in the context of congenital infection (128).

Neutralizing humoral immunity has been targeted throughout vaccine development efforts and is achieved by vaccinating against exposed glycoproteins ( $\mathrm{gB}, \mathrm{gH}$, and pentameric complex) 
important for viral entry into the cell. Neutralizing antibody responses have been associated with reduced transmission during pregnancy in observational human cohorts as well as nonhuman primates (119-123). But neutralizing antibody responses were only minimally elicited in the partially protective gB/MF59 vaccine trial $(118,124)$. While single immunogen vaccinations are capable of producing both humoral and cellular immune responses, it is possible that a CMV vaccine must include multiple antigens to effectively activate protective neutralizing and non-neutralizing humoral immunity and cellular immunity (131). One pre-clinical study using an mRNA vaccine platform to deliver multiple antigens was able to elicit robust neutralizing antibody titers and $\mathrm{T}$ cell responses, showing promise for both the mRNA vaccine platform and a multi-antigenic approach to CMV vaccines $(127,132)$.

\section{Vaccine Design Considerations}

The target population for a vaccine to prevent cCMV includes all women of child-bearing age, both seronegative women at risk of primary infection and seropositive women at risk of cCMV infection following re-infection or reactivation. While the optimal vaccine strategy would be effective in both groups, it may also be feasible to target the seropositive group alone as this group constitutes the majority of cCMV cases (133-135). Currently, the emphasis of vaccine developers is on women, and not men, because of the pregnancy-related transmission that vaccine efforts aim to prevent. Though men may facilitate transmission to pregnant women, the value of including men is unclear as of now.

A protective vaccine against cCMV must function in one or both of the following capacities: (1) prevent acquisition in seronegative mothers or reinfection in seropositive mothers; (2) reduce systemic viral load, infection of the placenta, and subsequent fetal infection $(123,136)$. Preclinical studies of protective immunity indicate that $\mathrm{CD} 4+\mathrm{T}$ cells are critical to viral control in pregnancy and that neutralizing antibodies alone toward surface glycoproteins may be insufficient for prevention of cCMV. Thus, the ideal vaccine will likely need to activate a polyfunctional antibody response in addition to a timely CMV-specific cellular response to achieve protection $(123,130)$. Moreover, strain-specific differences in CMV may modulate vaccine immunity and further studies on vaccine design are required to evaluate the value of including viral components from multiple strains. For example, there are five genotypes of $\mathrm{gB}$ which form two phylogenetic supergroups, and vaccination with one genotype may induce adaptive responses that are protective against only a subset of CMV strains (137). These findings may also support the idea that multiple antigens or antigen genotypes are needed in an effective vaccine to prevent CMV infection.

\section{How Close Are We}

A CMV vaccine is likely not as close as hoped due to limited knowledge of protective immunity, even after more than 40 years of research and high prioritization by the National Academy of Medicine. Greater opportunities for research and advocacy for universal CMV testing of neonates and identification of protective immunity are needed to be able to identify and treat congenital CMV and develop an efficacious vaccine.

\section{GROUP B STREPTOCOCCUS}

The gram-positive bacterium, group B streptococcus (GBS), colonizes the maternal vaginal tract and can lead to stillbirths and infection of the neonate by exposure during labor or an ascending infection of the amniotic fluid (138). Globally, 1 in 5 pregnant women are colonized by GBS, and $1 \%$ of all stillbirths are attributable to maternal GBS infection $(139,140)$. While only $1-2 \%$ of infants born to GBS colonized mothers have invasive bacterial disease, an estimated $10-50 \%$ of these cases are fatal $(138,141)$ Vertical transmission may lead to early onset of neonatal GBS disease in the first week of life, whereas late onset disease occurs in 7-90 days of life and is typically due to postnatal exposure to the pathogen from the colonized mother or the environment. Infant disease is characterized by sepsis, pneumonia, and respiratory distress, and in a subset, even meningitis. Of those infants who survive meningitis, 30$40 \%$ have neurodevelopmental impairments, leading to lifelong morbidity $(142,143)$. While peripartum intravenous antibiotic treatment with penicillin substantially reduces the incidence of early-onset disease, it does not confer any immunity to the newborn nor protect from late-onset disease (144). Also, some GBS isolates in the US and Japan have demonstrated decreased susceptibility to penicillin, indicating that antibiotic treatment may not be an adequate long term solution $(145,146)$. A vaccine is needed to protect infants from early as well as late onset GBS disease.

\section{Current Guidance}

The CDC and WHO recommends that all pregnant women who are colonized with GBS should be treated with antibiotics during labor. The indication for antibiotic prophylaxis include a GBSpositive culture of a vaginal or rectal swab upon screening in late pregnancy, pre-term labor ( $<37$ weeks), chorioamnionitis, prolonged labor, or ruptured membranes before labor $(147,148)$. This is because high levels of maternal colonization, fever, and prolonged rupture of membranes are risk factors for earlyonset GBS disease in newborns $(149,150)$. With $98 \%$ of women receiving GBS testing in the US, incidence of early onset GBS has decreased to 0.25 per $1,000(151,152)$. Yet, there are several challenges to implementation of timely screening in low resource settings (153).

\section{Protective Immunity}

Capsular polysaccharide (CPS)-specific maternal IgG levels correlate with protection from neonatal GBS disease. In the mouse model, infusion of human CPS IgG protected from challenge, indicating the antibodies are sufficient for mediating serotype-specific protection from disease $(154,155)$. Observational studies of natural immunity to GBS infection in the US, Europe, and South Africa indicate that the threshold for protection against early onset neonatal disease is maternal CPSspecific IgG in the range of $0.5-10 \mu \mathrm{g} / \mathrm{mL}(156-160)$. While the association between the magnitude of maternal IgG and neonatal 
protection is consistent across populations, further studies are needed to confirm an appropriate correlate of protection that can serve as an endpoint in vaccine trials. Specifically, standardization of CPS-specific IgG binding and functional assays, antigens, and reference sera will facilitate progress (161). GBS-binding antibodies mediate several functions; including opsonizing bacteria, direct complement mediated killing, and phagocytosis. These functions are cumulatively measured by in vitro opsonophagocytic assays. One study shows that maternal IgG concentrations $>1 \mu \mathrm{g} / \mathrm{mL}$ facilitate GBS killing and reduce risk of early onset neonatal disease by 81 and $78 \%$ for serotypes Ia and III (158). In contrast to antibodies, CPS-specific immune cell activation is associated with clearance of homotypic GBS rectovaginal colonization during pregnancy, but not with the magnitude of CPS-specific IgG and opsonophagocytic activity, which are required for protection (162). Altogether these data indicate that antibodies are crucial to protection from GBS.

In order to protect newborns from early and late onset GBS, antibodies must be transferred across the placenta and remain at protective levels in the infant through 3 months of age, a time period of greatest risk of GBS disease. The concept of maternal immunization to promote transplacental transfer of $\operatorname{IgG}$ and protect neonates from GBS infection has been tested in baboons, mice, and rabbit models. These studies show increased survival in offspring of vaccinated animals upon challenge with serotype matched GBS, and functionally equivalent levels of antibody transfer from mother to offspring (163-165). Cumulatively, these studies support further development of glycoconjugate vaccines that elicit strong CPS-specific IgG in pregnancy for prevention of neonatal GBS.

\section{Vaccine Design Considerations}

The leading vaccine candidates are CPS-protein conjugate vaccines. Specifically, the CPS conjugated to CRM197 (a nontoxic diphtheria toxin carrier protein) or tetanus toxoid, have been tested in Phase II vaccine trials as well as pregnant women. Since 5 GBS serotypes (Ia, Ib, II, III, IV) account for $97 \%$ of global neonatal GBS disease, vaccine candidates are designed to include one or multiple CPS antigens from these serotypes (166). Tetanus toxoid conjugate vaccines have been shown to be safe and immunogenic in non-pregnant as well as pregnant women (167-169) Antibody responses have been dose-dependent and elicited opsonophagocytic activity against matched GBS serotypes in vitro (167-169) In Phase II studies, administration of a second dose of a trivalent CPSCRM197 vaccine candidate in non-pregnant subjects shows seroconversion with $>8 \mu \mathrm{g} / \mathrm{mL}$ CPS type-specific IgG in $>94 \%$ of participants for each serotype (Ia, Ib, and III). Antibody responses to glycoconjugate vaccine candidates peaked in their opsonophagocytic activity 4 weeks after immunization, declined substantially by 1 year, but persisted through 2 years (170). More recently, antibodies against the GBS surface proteins alpha and rib have been associated with less neonatal disease, suggesting that vaccines based on these conserved bacterial proteins may provide cross-serotype protection (171). These trials suggest that the glycoconjugate platform is effective immunogenic in the critical window of pregnancy.
Many features of disease and immunity support a maternal vaccine in pregnancy as the optimal strategy for prevention of neonatal GBS: (1) the risk to newborns is greatest in the days after birth, before a time when they may mount their own immune response; (2) transplacental transfer of antibodies at a protective level is feasible; (3) vaccine elicited immunity of current candidates is greatest in the weeks after immunization and wanes thereafter, supporting immunization immediately preceding the window of greatest risk to the newborn.

\section{How Close Are We}

Due to the low neonatal disease incidence amongst live births (1-3 cases per 1,000), the sample size to test efficacy with the endpoint of reduced perinatal transmission may not be feasible (161). Therefore, identifying correlates of protection for each serotype that are consistent across countries will be a crucial pathway to vaccine licensure (172). What remains now is to clearly define the correlate of protection with further studies across populations and standardization of binding and functional antibody responses. With nearly 30 years of clinical trial data and strong safety and immunogenicity profile of vaccine candidates in pregnancy, a GBS maternal vaccine is feasible in the near future.

\section{HERPES SIMPLEX VIRUS (HSV)}

The prevalence of HSV types 1 and 2 among adolescents and young adults is 47 and $11 \%$ in the US, and type 2 is associated with genital herpes (173). Neonatal herpes infection affects $\sim$ every 1 in 3,200 births $(174,175)$. The majority $(85 \%)$ of neonatal HSV infections are acquired peripartum during vaginal birth, $10 \%$ are acquired after birth from maternal mucosal virus shedding and $5 \%$ are acquired in utero (176). Evidence suggests that cesarean delivery is an option to reduce the risk of neonatal HSV, though not protective in all cases (177-179). Whereas, acyclovir administration in late pregnancy reduces viral shedding at delivery, impact on neonatal HSV has not been quantified $(180,181)$. Notably, risk of transmission is highest for pregnant women with a primary HSV infection during pregnancy (30$50 \%$ ), as compared to seropositive women with recurrent HSV in pregnancy (1\%) (177). These transmission rates indicate that preexisting maternal immunity has a protective role in preventing vertical HSV transmission.

\section{Current Guidance}

There are three patterns of HSV disease in newborns that can be identified within the first 3 weeks after birth. The first is localized cutaneous infection involving skin, eyes, and mouth observed in $45 \%$ of neonatal HSV infections (182). The second is infection of the central nervous system (CNS), which is observed in $30 \%$ of infants (182). The third is a disseminated infection that encompasses multiple organs in $25 \%$ of HSVinfected newborns (182). Though intravenous administration of $60 \mathrm{mg} /$ day of acyclovir for 3 weeks has reduced infant mortality, $\sim 29 \%$ of infants with disseminated disease and $4 \%$ of infants with CNS disease continue to die within the first year of life (183). Moreover, neonatal infection may lead to the development of a latent viral reservoir and reactivation of 
infection (184). Relapse of HSV infection can worsen disease and survival prognosis with conditions such as recurrence of skin lesions, infection of CNS, and severe neurologic and behavioral impairments (184-186). Though treatment has reduced infant mortality, preventative measures are needed to eliminate infant mortality due to congenital HSV and curb worsening neurologic pathologies resulting from reactivation of latent viral reservoir.

\section{Protective Immunity}

Immune responses that protect against HSV infection are characterized by a robust tissue-resident $\mathrm{T}$ cell responses, which can lower viral burden in the genital tract and decrease transmission of infection to dorsal root ganglia, where HSV may establish latent infection and reactivate to cause recurrent disease later in life. It has been found that depleting $\mathrm{T}$ cells prior to HSV2 challenge in mice leads to more severe disease as compared to $\mathrm{B}$ cell depletion, indicating the prominent role of T cell responses $(187,188)$. Moreover, when HSV infection is not active, vaginal biopsies reveal increased levels of effector $\mathrm{CD} 8+\mathrm{T}$ cells, indicating the importance of this cell type in viral control (189).

Maternal antibodies also have a role in supporting clearance of HSV infection and providing passive protection to the fetus. $\mathrm{B}$ cells and their corresponding antibodies reduce the time to resolving viremia upon infection as compared to B cell depleted mice, but passive transfer of antibodies alone does not prevent infection in naïve mice (187). Recent findings from murine models of maternal immunization indicate that protection of pups from passively transferred maternal antibodies is associated with antibody-dependent cellular cytotoxicity (ADCC), suggesting that ADCC-mediating antibodies may be more relevant to neonatal protection than neutralizing antibodies (190). Importantly, evaluation of intravaginal vaccines in the guinea pig and mouse models indicate that this vaccination route increases levels of IgG and IgA in the genital tract, the site of primary exposure to HSV $(191,192)$. These studies demonstrate that while HSV-specific antibodies can support viral clearance, they cannot alone prevent infection and recurrent disease.

There are several ways in which vaccines strive to elicit protective cell-mediated immunity. Recently a single replication HSV2 vaccine candidate with a deletion in the viral cell entry protein, glycoprotein D, was tested in mice and showed protection from lethal challenge (193). Intriguingly, this protection correlated with $\mathrm{Fc}$ receptor activating antibody titers and not neutralizing titers, reinforcing the importance of antibodies that facilitate immune cellular activity (193). While subcutaneous vaccination strategies have led to increased levels of circulating HSV-specific CD8+ T cells, this does not translate to higher levels of HSV-specific CD8+ T cells migrating to the genital tract, leading to ineffective protection and the need for novel strategies to elicit tissue-specific immunity (194). New vaccination approaches, such as the "prime and pull" strategy, are being developed to boost tissue-specific immunity. To test this strategy, mice and guinea pigs were immunized subcutaneously with attenuated HSV2 or a combination of HSV2 glycoproteins, and this "primed" systemic immune response was "pulled" toward the vaginal tract by topical application of tolllike receptor agonists (imiquimod) or chemokines that attract CD8+ T cells (CXCL9 and CXCL10) following vaccination (195, 196). This protected mice from lethal HSV2 challenge, and led to substantial increases in the magnitude of and longevity of HSV-specific CD8 $+\mathrm{T}$ cells in the vaginal tract as compared to subcutaneous vaccination alone (196). In addition to robust and lasting mucosal immunity, identifying appropriate topical products that "pull" the immune response, but do not cause unwanted inflammatory responses will be a key factor in the success of such innovative vaccine strategies (196). Altogether, these studies indicate that preventing maternal primary or secondary HSV infection requires robust mucosal immunity and long lasting HSV-specific tissue-resident CD8+ T cells.

\section{Vaccine Design Considerations}

Despite progress in our understanding of protective immunity, vaccine candidates tested in guinea pig and mouse animal models have not translated to effective candidates in vaccine trials (197). There are several subunit and live-attenuated vaccine candidates that have been tested in vaccine trials (198). The Herpevac trials which contained the glycoprotein-D subunit of HSV2 demonstrated partial efficacy of $58 \%$ in protecting against HSV1 in seronegative women, and an overall efficacy of $20 \%$ against both HSV1 and HSV2 (199). Analysis of immune responses that led to protection in this subset indicated high neutralizing antibodies as a correlate of protection (200). Similarly, the Chiron HSV vaccine composed of HSV2 glycoprotein-B and glycoprotein-D subunits elicited neutralizing antibodies but failed to protect against HSV2 infection (201). These trials were halted due to low efficacy against HSV2 and indicate that neutralizing antibodies alone are insufficient in preventing primary infection, viral persistence, or recurrence of disease. Achieving greater efficacy will likely require a more robust cellular response and adjuvants tailored to the desired CD8+ T cell response.

Other platforms such as replication defective live-attenuated HSV2 (HSV529) and DNA vaccine encoding HSV2 glycoprotein$\mathrm{D}$ (COR-1) are being tested in Phase 1 trials to improve cellular responses $(202,203)$. Thus far, these candidates are shown to be safe in humans, and the HSV529 elicits neutralizing antibodies and modest $\mathrm{CD} 4+\mathrm{T}$ cell responses in HSV seronegative vaccinees (202). In addition, there are other subunit vaccines in preclinical development that are assessing combinations of different viral antigens with novel adjuvants to stimulate $\mathrm{CD} 4+$ and CD8+ T cell responses $(204,205)$.

\section{How Close Are We}

The primary strategy to prevent congenital HSV is to immunize prior to conception to confer HSV immunity during pregnancy and reduce likelihood of reactivation and congenital transmission. In the absence of a vaccine that induces sterilizing immunity, even a partially effective vaccine that controls viral shedding could reduce congenital disease burden since isolation of HSV from the mother's vagina at delivery is associated with a 300 -fold increase in the risk of neonatal infection (177). While the vaccines candidates tested thus far do not 
protect adequately from HSV2 acquisition, it is unclear if they would limit vertical transmission with differential efficacy, since analyses were conducted in non-pregnant populations. Testing of diverse vaccine candidates in clinical and pre-clinical trials gives hope that a vaccine to protect from perinatal HSV infection is feasible.

\section{HUMAN IMMUNODEFICIENCY VIRUS (HIV)}

HIV can be vertically transmitted from mother to infant in utero, during delivery, or postnatally during breastfeeding. In 2018, $\sim 1.7$ million children worldwide under the age of 15 were living with HIV and over 160,000 infants were newly infected with HIV primarily via mother to child transmission (MTCT) (206). While HIV-infected infants could remain asymptomatic for years, HIV can progress to AIDS if left untreated, characterized by a severely damaged immune system with a CD4 $+\mathrm{T}$ cell count $<200$ and increasing frequency of severe, opportunistic infections. In the absence of interventions during or after pregnancy, rates of mother to child transmission (MTCT) are between 30 and $40 \%$ but the introduction of antiretrovirals therapies (ART) during pregnancy and breastfeeding has reduced MTCT rates to as low as $2 \%$ (207). Since the majority of HIV-positive individuals are started on ART following diagnosis, the primary observed impacts of HIV infection are typically related to the lifelong treatment. While ART inactivates replicating virus, the drugs cannot abolish the latent viral reservoir that results from infection, causing lifelong dependence on this drug. While ART in HIV-infected children prevents disease progression to AIDS, ART has been associated with metabolic complications including lipodystrophy, dyslipidemia, insulin resistance, lactic acidosis, and loss of bone density (208). Thus, additional options to support current prevention strategies against perinatal HIV transmission are needed to eliminate the pediatric HIV epidemic.

\section{Current Guidance}

It is recommended that all pregnant women be tested for HIV during their first antenatal visit. Subsequent, testing in the third trimester is advised for pregnant women with negative initial HIV antibody tests if they are considered at increased risk of HIV acquisition, or reside in jurisdictions with elevated HIV incidence or that require third-trimester testing (209). According to the World Health Organization's (210) clinical treatment recommendations, all pregnant and breastfeeding women regardless of WHO clinical stage and $\mathrm{CD} 4+\mathrm{T}$ cell count should receive the Option B plus treatment strategy, which consists of triple combination fixed-dose ART, immediately upon diagnosis and continued for life. A primary risk factor for MTCT of HIV is maternal plasma viral load, other risk factors include maternal disease progression, $\mathrm{CD} 4+\mathrm{T}$ cell counts, mode of delivery, prematurity, and breastfeeding (211).

\section{Protective Immunity}

In the absence of ART, the rate of MTCT of HIV is $<50 \%$, suggesting that there exist maternal immune factors that contribute to protection. Identification of these immune correlates of protection could inform the types of immune responses that maternal HIV immunization strategies may need to elicit to prevent transmission to an infant (24). Maternal antibodies against conserved portions of the HIV envelope (Env) have been suggested to have protective effects against transmission although the results have not been consistent across studies. Factors such as the magnitude of maternal IgG responses to the third variable loop or CD4 binding site of the HIV env gene, and the magnitude of neutralizing antibody responses against easy-to-neutralize (tier 1) viral variants were predictive of reduced risk of MTCT in the US-based Women and Infants Transmission Study (WITS) cohort (212). Whereas, increased risk of MTCT was associated with antibodies against $\mathrm{CD} 4+\mathrm{T}$ cell binding sites in the HIV envelope and HIV's variable loop 1 and 2 (V1V2) (213). Moreover, the presence of gp41 epitopespecific antibodies is associated with reduced risk of transmission in HIV subtype C-infected mother-child pairs (214). These conflicting results indicate that while there are potentially protective humoral immune responses against HIV Env, these responses differ depending on virus clade, transmission mode, and maternal antiretroviral use $(213,215,216)$.

Maternal autologous virus neutralizing antibody responses are another immune factor that has been increasingly studied in the context of MTCT of HIV. MTCT is characterized by a virus genetic bottleneck in which infant infection is established by a single or a few maternal transmitted-founder $(\mathrm{T} / \mathrm{F})$ viral variants (217-219). Though the maternal and infant factors that drive selection of infant $\mathrm{T} / \mathrm{F}$ variants are not well-understood. Recent studies have found that infant $\mathrm{T} / \mathrm{F}$ viruses are more neutralization resistant to paired maternal plasma neutralizing antibodies as compared to maternal non-transmitted viral variants (218). However, some studies have indicated that transmitting mothers as compared to non-transmitting mothers have higher breadth and potency of neutralizing antibody responses (220). These infant $T / F$ viruses are generally neutralization sensitive to most broadly neutralizing antibodies (bnAbs). Yet, a recent study has revealed the occurrence of escape of the infant transmitted virus variant from a mother's plasma bnAb response, indicating that a single specificity bnAb response will not be sufficient to eliminate MTCT (221). Together, these studies suggest the potential for boosting maternal autologous virus neutralization by eliciting multispecific bnAb responses to further prevent MTCT (218).

Current research into passive and active immunization strategies for preventing MTCT is being conducted in both non-human primate (NHP) models and clinical trials. In the simian immunodeficiency virus (SIV) model, SIV-exposed infant macaques were protected against transmission by passive immunization with hyperimmune globulin (222). Rhesus macaque models utilizing chimeric simian-human immunodeficiency virus (SHIV), in which includes the HIV envelope, have also shown that post-exposure passive immunization of infants or mother-infant pairs with neutralizing monoclonal antibodies led to complete protection from virus acquisition $(223,224)$. Human clinical trials have tested treatment of HIV-infected pregnant women and infants with HIV hyperimmune immunoglobulin (HIVIG) in order to assess HIVIG safety and efficacy when combined with ART drugs like nevirapine and zidovudine $(225,226)$. While HIVIG 
administration had no adverse effects on pregnancy, there was no statistically significant difference in HIV perinatal transmission, showing that results from the promising NHP model did not translate to efficacy in humans $(225,226)$. Preliminary maternal HIV vaccination trials have established the safety and feasibility for delivery of viral envelope-based alum-adjuvanted vaccines in HIV-infected pregnant women on ART (227). Though the efficacy of this approach remains to be tested.

\section{Vaccine Design Considerations}

A promising area of research is the development of a pediatric $\mathrm{HIV}$ vaccine that can elicit lifelong bnAb responses targeting locations on the HIV Env protein. Passive administration of bnAbs to NHPs can prevent transmission and establishment of viral infection, providing proof of principle that bnAbs of sufficient breath and potency could induce protective immunity (224). Current approaches to bnAb elicitation explore use of multi-component sequential regimens that incorporate HIV Env epitope-specific immunogens, antibody lineage-based immunogens, and/or germline-targeting immunogens to drive antibody maturation from B cell precursors toward bnAbs (228). Yet, these approaches are likely to require long term multidose, immunization strategies. BnAb targeting vaccines are of particular interest as a vaccination strategy to elicit long-term protective HIV immune responses in early childhood that will provide protection into adolescence, prior to the risk of sexual transmission. Recent studies have suggested that HIV-infected children are able to develop broader and more potent virus neutralization earlier than adults and via a distinct mechanistic pathway, highlighting potential advantages of the childhood immune landscape for eliciting broadly neutralizing antibodies compared to adults (229-232).

\section{How Close Are We}

Despite more than 40 years of intensive research and investments in the field, HIV continues to be a challenging pathogen to address as it mutates away from vaccine immunity, presents highly complex epitopes, and consists of a spectrum of strains with high viral diversity. While clinical trials and the non-human primate model have revealed trends in immunity required to control the virus, these trends have varied across populations and viral strains leading to several hurdles for vaccine design (233). Promising strategies like the elicitation of bnAbs do not have a licensed precedent in medicine and have not been tested in clinical trials. Therefore, much research is still required to generate an effective vaccine for elimination of perinatal and lifelong infection with HIV.

\section{TOXOPLASMA}

Toxoplasma gondii is a parasite prevalent in the world with up to one third of the world population infected (234). The percentage of women infected in child bearing years varies depending on the region. In developed countries, between 10 and 50\% are infected, however in the tropics this rate can be as high as $80 \%$ (235). Such a high global prevalence of this parasite is facilitated by its partial life cycle in feline species, which co-inhabit with humans, ability to infect ubiquitous mammals and birds that we eat and live around, and ability to survive in the external environment without degradation. To do this, Toxoplasma gondii has a particularly complex life cycle with two main stages: the sexual life cycle which occurs in felines and results in oocysts that are transmitted in cat feces, and the asexual life cycle occurs in mammals or birds (236). The parasite takes different forms in each phase of its life cycle allowing it to adapt to each host and infect. The two life cycle phases that may progress in humans are known as, tachyzoites, which rapidly replicate, and the bradyzoites, which are the more inactive and form cysts in tissues (236). Not only do these cysts inhibit organ function, but they also contain concentrated amounts of parasites which facilitate vertical transmission. Consequently, the parasite is typically transmitted by ingesting contaminated undercooked meat and unwashed vegetables or fruit, and directly through handling and subsequent incidental ingestion of the parasite in cat feces or contaminated soil (234).

Infection results in the disease Toxoplasmosis. Most immunocompetent individuals have no symptoms (subclinical), however pregnant women and immunocompromised individuals such as HIV-infected individuals and transplant patients can have life threatening complications due to cysts and infection of organs like muscles, brain, heart, lung or placenta (237). Specifically for the fetus and newborn, toxoplasmosis can result in hydrocephaly, intellectual disability, seizures or death (237). Timing of congenital infection by trimester of pregnancy and severity of injury to the fetus are inversely related. During the first trimester of pregnancy infection results in a low transmission frequency $(<6 \%)$ to the fetus but has the most detrimental consequences if transmission does occur (234). Whereas, infection in the third trimester transmission is much more common $(60-80 \%)$, but results in lesser severity of disease in the fetus (234).

\section{Current Guidance}

There is no vaccine for $T$. gondii, and in fact vaccines are not a high priority given effective treatment options in pregnancy and widespread prevention counseling in prenatal clinical visits. Prevention of Toxoplasma congenital infections is based on following proper hygiene guidelines during pregnancy, such as washing hands, avoiding eating raw or undercooked meat or unwashed vegetables, and importantly, not handling cat feces (238). Systematic Toxoplasma screening is recommended for all pregnant women, as early in the pregnancy as possible, and is based on serology to assess for the presence of T. gondii IgM antibodies. If detected, infection is treated with pyrimethamine and sulfadiazine, which kill the replicating tachyzoite stage of the parasite (239). Since pyrimethamine may be teratogenic in early pregnancy, it is only recommended after 18 weeks of gestation (240). These treatments are highly effective for prevention of congenital T. gondii infection, and have shown to reduce incidence of congenital infection up to $60 \%$ as compared to historical controls without treatment (240). However, if congenital infection does occur then newborns are also offered these treatments. One of the main drawbacks to the current treatment approach is that $T$. gondii has multiple stages in its 
lifecycle and the drugs have less efficacy against the slow dividing bradyzoites (239).

\section{Protective Immunity}

Immunological control of T. gondii infection requires both innate and adaptive immune responses. A TH1 response through tolllike receptor (TLR) sensing of the parasite in tissues followed by IL-12 and IFN $\gamma$ production are critical for control of cyst formation (241). Also, dendritic cells and neutrophils are important to parasite control as depletion of these immune cells results in an increased burden of cysts and downstream health complications $(242,243) . \mathrm{CD} 4+$ and $\mathrm{CD} 8+\mathrm{T}$ cell responses and a robust antibody response including $\operatorname{IgM}, \operatorname{Ig} \mathrm{A}$, and $\operatorname{IgE}$ antibodies develop by 2 weeks post infection, suggesting an essential role for T cells, mucosal antibodies, and/or extracellular antibody effector functions (234). The importance of $\mathrm{T}$ cell responses is demonstrated in HIV patients, where there is a lack of ability to control the infection in patients with reduced CD4+ T cells and also in mouse models lacking CD4+ T cells $(244,245)$. Although reinfection can occur, a prior exposure to this pathogen and immune response limits spread of the parasite throughout the body. Given that natural immunity does not prevent reinfection, a vaccine would have to provide more robust immunity than natural infection to be effective.

\section{Vaccine Design Considerations}

The multiple life stages of parasites are particularly complex for vaccine design, as these pathogens change substantially over the course of infection. Thus far, there are no licensed vaccines to prevent parasitic diseases, and treatments have been largely effective given their low rates of mutation as compared to viral and bacterial pathogens (246). A vaccine may require targeting of important immune responses required for prevention of infection such as MHC class I restricted CD8+ T cells and $\operatorname{IFN} \gamma$ (247).

In pregnant women prior immunity to $T$. gondii is not sufficient to prevent transmission to the fetus although transmission and severity of injury to the fetus is reduced (248). Vaccine development has been ongoing for the last 30 years, with a focus on prevention of tissue cyst development and vertical transmission in livestock and felines, which are the primary sources of human exposure to the pathogen (249). Blocking the pathogen prior to cyst formation is critical as cysts shield parasites from immune detection and responses, and thereby enable infection and transmission. Thus, parasite control mediated by vaccine-elicited immunity is more feasible before to cyst formation. An example of this approach is the licensed Toxovax ${ }^{\circledR}$ vaccine for sheep. Toxovax ${ }^{\circledR}$ is a live attenuated vaccine consisting of the $\$ 48$ strain of tachyzoites that reduces abortion rates in sheep and tissue cyst formation (250). However, the disadvantage of Toxovax ${ }^{\circledR}$ is its short shelf life, and incomplete protection. Due to its limited application in breeding ewes, the primary focus of Toxovax ${ }^{\circledR}$ is to improve livestock yields and not for prevention of congenital toxoplasmosis in people.

\section{How Close Are We}

The strategy to vaccinate livestock and household pets is a novel approach to preventing congenital infections, and depends upon high levels of implementation, as pockets of unvaccinated pets and livestock can endanger pregnant women and newborn health. Importantly, this strategy may not be effective in low-income countries where disease burden is greatest due to economic constraints of purchasing vaccines for livestock with limited household income (251). Given the low rates of congenital transmission and options for screening and treatment, development a human vaccine for $T$. gondii continues to be low priority for research. In place of a vaccine, increasing access to screening and drugs may be a more urgent and effective alternative.

\section{SYPHILIS}

Syphilis, a sexually transmitted infection caused by the spirochete bacterium Treponema pallidum, infects 36 million people globally and annually impacts 988,000 pregnancies that result in 661,000 cases of congenital syphilis (CS) per year worldwide (252). Mother to child transmission is the second leading cause of still birth and miscarriage worldwide. Of pregnant women with untreated syphilis globally, 53\% have an adverse birth outcome, with $16 \%$ of infants with clinical disease (2). Transmission can occur any time during pregnancy. While penicillin can treat this disease, there is rise in newborn infections, mostly due to low coverage of antenatal screening and rising numbers of maternal infections in the general U.S. population $(1,2)$.

Despite growing recognition of the need to bolster public health interventions and develop a complementary vaccine strategy, there is a lot that remains unknown about the biology of $T$. pallidum and immunity required to protect against it. An important reason to complement these implementation challenges with more urgent vaccine development efforts is due to the rise of antibiotic resistant syphilis strains, suggesting that alternative approaches to penicillin will soon be required (253). In the absence of longstanding syphilis vaccine research, maternal immunity may provide clues as to the immunity required for protection. It is known that mothers who are later in their infection, are substantially less likely (10\%) to transmit syphilis to their fetus as compared to those in early infection (40-70\%) (254). This indicates that development of adaptive immunity over the course of infection offers substantial protection from congenital disease, and a vaccine could elicit similar types of immunity. Intensive research on the genetic variability across syphilis strains and protective immunity must take place before developing a vaccine to prevent CS.

\section{Current Guidance}

Congenital Syphilis is highly treatable using antibiotics, benzathine penicillin G (255). The CDC mandates syphilis screening at the first prenatal visit, and recommends follow-up screening in early third trimester and delivery in higher risk populations. Syphilis is diagnosed by treponemal or nontreponemal serologic tests which detect syphilis antibodies against these different life stages for the bacterium. Since these 
tests may have lower sensitivity in early infection, the diagnosis also consists of evaluation of sexual history and exclusion of other diseases. Once diagnosed in pregnancy, 1-3 doses of penicillin (2.4 million units total) are administered intramuscularly to treat the disease. While this is considered curative for the fetus as well, upon birth, the infant also undergoes syphilis serology testing and may receive the treatment.

Despite treatment availability, the majority of congenital infections in high resource settings like the US occur because the mother is unaware of her infection status, due to lack of testing and difficulty in diagnosing low grade early infections $(256,257)$. Lesions from primary infections can be painless and difficult to detect, whereas secondary and tertiary stages of syphilis can persist without symptoms or be misdiagnosed due to the non-descript nature of symptoms. This leads to missed opportunities for detection and treatment. Moreover, policies for implementation of screening is a critical issue. For example, a 2016 study identified that 6 US states did not require prenatal screening for syphilis at the first visit (257).

Meanwhile, in low- and middle-income countries syphilis remains at endemic levels due to lack of access to antenatal care visits, missed screening at these visits, and increase in prevalence among key populations such as men who have sex with men and female sex workers $(1,258,259)$. Additionally, there are global drug shortages of benzathine benzylpenicillin, the treatment for syphilis which has been placed on the essential medicines list by the WHO. Projections of unmet drug need for 30 high burden countries indicate a doubling of penicillin required for mothers and infants if screening guidelines were met for $95 \%$ of the population (260). Fulfilling this need would prevent 95,938 adverse birth outcomes and 37,822 stillbirths (260). Therefore, despite effective diagnostic and treatment options, CS has not been controlled in low or high resource settings due to persistent structural and implementation barriers.

\section{Protective Immunity}

T. pallidum infection occurs in the mucosa or skin following sexual contact. Spirochetes directly attach and replicate below the skin, and subsequently spread through the blood and lymphatics (261). Cellular immune infiltrates are seen at the sites of replication (262), after sensitization $\mathrm{T}$ cells respond to outbreak infections with a delayed type hypersensitivity response, which is associated with clearance of the bacterium (263). Antibodies are also thought to control infection. Following primary infection, high levels of $\operatorname{IgG}$ is detected against $T$. pallidum proteins, which are important for opsonization and phagocytosis of the bacterium by macrophages (264). Until 2018, studies of T. pallidum have been hindered by an inability to culture this organism long-term in vitro; this technology now enables improved evaluation of immunity to this pathogen (265).

Proof of concept for vaccination was shown in 1973 where rabbits were vaccinated with irradiated bacteria 60 times in 37 days and were fully protected from challenge for at least a year from the homologous bacterium strain (266). This work showed that antibodies directed toward native epitopes on the outer membrane of virion surface would be sufficient for protection. However, IgG elicited from infection with one strain is less protective against heterologous strains, suggesting that vaccine design must account for diversity across strains.

Currently, the primary focus for vaccine development is identifying appropriate immunogens. This research has led to characterization of outer membrane (OM) proteins of the bacterium. Identification of OM structures is complicated in $T$. pallidum due to few proteins in the $\mathrm{OM}$ and fragility of the bacterium, which makes isolation of OM proteins difficult (261). Advances in bioinformatics have increased the identification of the outer membrane proteins, such as TrpK and reinvigorated funding for identifying a vaccine for Syphilis (267).

\section{Vaccine Design Consideration}

A vaccine to prevent CS should go hand in hand with key public health interventions to improve screening and treatment in pregnancy. Given the population level morbidity, implementation challenges, and high sexual transmission rates, the target vaccine to prevent CS would not only elicit protective immunity prior to pregnancy but also minimize transmission. Therefore, the target population would be men and women prior to sexual debut. Since primary infection in pregnancy leads to higher rates of congenital transmission than later in the course of infection, the target syphilis vaccine will need to protect seronegative populations.

Given the challenges with culturing T. pallidum and making large quantities for inactivation or attenuation, a strategy of using bacterial antigens as vaccines is particularly promising. Similar to the pneumococcus, meningitis, and Haemophilus influenzae type $B$ vaccines, these bacterical antigens can be presented as a conjugate vaccine with optimized carrier and adjuvants. Additionally, conjugate vaccines have a strong safety profile for administration to pregnant women at all stages of pregnancy (255).

\section{How Close Are We}

Priority for vaccine development and syphilis research has been low due to the availability of penicillin as a treatment for syphilis. However, implementation challenges associated with timely screening and treatment have led to a failure to eliminate CS thus far. Importantly, resistant strains threaten the effectiveness of this approach in the future. Development of a vaccine would be extremely beneficial for prevention of syphilis related still births and congenital infection. A syphilis vaccine may also contribute to control of HIV infection as syphilis infection is associated with enhanced HIV transmission (237).

\section{ZIKA VIRUS (ZIKV)}

Zika virus (ZIKV) is the most recently discovered congenital pathogen and transmits from mother to child during pregnancy in $\sim 1$ out of $10 \mathrm{ZIKV}$-infected pregnancies (268-270). The congenital route of transmission for ZIKV was first identified during the 2015-2016 outbreak in the Americas (271, 272). However, ZIKV may spread sexually, and primarily via the ubiquitous Aedes genus mosquito vector (273). In healthy individuals, ZIKV infection may be asymptomatic or cause a mild short-lived febrile disease with rashes, conjunctivitis, 
and arthralgia (274). Whereas, Congenital Zika Syndrome (CZS) is much more severe outcome and characterized by an array of conditions including neurodevelopmental disabilities, microcephaly, visual impairments, motor delays, and reduced mobility due to muscle contractures $(268,275,276)$. These conditions cause lifelong disability. In one cohort, one third of infants born to mothers with ZIKV-infection in pregnancy presented with below average scores for neurodevelopment, and abnormal vision, hearing, and language function by the age of two (276). There have also been reports of cardiac defects, and development of microcephaly and autism in early life (276). It is estimated that a single CZS case would result in $\$ 100$ million in healthcare costs in the United States (277). The burden of Zika disease on congenitally infected newborns has motivated intensive research and unprecedented collaborations to publishing findings rapidly for vaccine development.

Though the ZIKV outbreak of 2015-16 has subsided, the virus may re-emerge after years as the population grows susceptible to sustain transmission, like other flaviviruses. The virus is capable of infecting urban primate populations in South America that could serve as a reservoir for future outbreaks, or alternatively buffer outbreaks through immunity (278-280). The previous ZIKV outbreak led to microcephaly in 11,000 newborns in Brazil and decline in fertility rate on a national level $(281,282)$. If the virus were to return after years, these devastating consequences for people and countries must be prevented by a vaccine or intervention that is effective in pregnancy.

\section{Current Guidance}

Presently, there are no licensed vaccines or antivirals for the prevention or treatment of Zika virus in pregnancy, the time period of greatest risk to the fetus. Given the lack of therapeutic options and the lifelong burden of disability, the primary guidance is to prevent ZIKV-infection in pregnancy. Pregnant women are advised to avoid travel to ZIKV-endemic areas, minimize mosquito exposures, and protect against sexual transmission during pregnancy (283). Condom use or abstinence from sexual contact after travel to endemic regions is recommended for up to 3 months with a male partner, due to prolonged persistence of ZIKV RNA in semen (283). Moreover, community mosquito control for arbovirus outbreaks in densely populated areas may help to reduce transmission but does not offer complete protection, as mosquito populations may be missed and rebound (284).

Pregnant women living in outbreak areas with symptoms or travel exposure history may be tested via a PCR test for the presence of viral RNA or presence of ZIKV-specific IgM for up to 12 weeks from exposure. While the PCR diagnostic is most effective in acute infection, the CDC supports longer testing in pregnancy as ZIKV may persist up to 3-times longer in pregnant as compared to non-pregnant women $(285,286)$. After birth, infants suspected of in utero ZIKV exposure may be tested for ZIKV RNA or IgM, even though the molecular test is most effective within 10-14 days of acute infection and there is no reliable infant diagnostic (287). While ZIKV RNA and infectious virus has been reported in breast milk, postnatal transmission via this route has not been reported and thus breast feeding of newborns by ZIKV-exposed mothers continues to be recommended by the WHO (288).

\section{Protective Immunity}

Knowledge on immunity required to protect against ZIKVinfection comes primarily from interferon knockout mouse models, non-human primate models, and observational cohorts of mothers and infants sampled during the recent outbreak (289-291). In the aftermath of 2015-16 outbreak, several vaccine candidates were developed and tested in mice and NHPs, including an envelope (E) and pre-membrane (prM) viral protein encoded as a DNA vaccine and mRNA vaccine, purified inactivated virus, live attenuated vaccine, and adenovirus vectored $\mathrm{E}$ and prM. All candidate vaccines protected non-pregnant NHP and interferon knockout mice from challenge (292-296). Moreover, neutralizing mAbs and purified immunoglobulin from immunized monkeys protected non-pregnant NHPs from ZIKV challenge, suggesting that high titers of neutralizing antibodies alone may serve as a correlate of protection $(292,295)$. Based on these promising findings, the DNA vaccine encoding $\mathrm{E}$ and prM viral proteins was tested in Phase I clinical trials and shown to be safe and immunogenic in humans (297). Yet, in pregnant NHPs, the leading DNA vaccine candidate and neutralizing monoclonal IgG therapeutics have failed to provide sterilizing maternal and fetal immunity with cases of fetal viremia and brain pathology despite vaccination $(298,299)$.

As an alternative to the vaccine candidates based on structural viral proteins, such as E, vaccine designs with non-structural protein 1 (NS1) have also been tested in the mouse model. The NS1 based candidates demonstrate reduced viral load and improved survival in mice but cannot offer sterilizing immunity as NS1 is not externally displayed on the virion for neutralization $(300,301)$. In improving vaccine design to protect in pregnancy, an E and NS1 combined vaccine design may be considered in the future.

Studies of human responses after ZIKV infection indicate rapid elicitation of plasmablasts and establishment of a ZIKVspecific memory B cell population, supporting the protective role for B cell immunity and ZIKV-specific antibodies $(302,303)$. Furthermore, analyses of human T cell peptide epitopes shows that ZIKV specific CD8+ $\mathrm{T}$ cells react more to structural proteins whereas $\mathrm{CD} 4+\mathrm{T}$ cells have a greater response to non-structural viral proteins (304-306). Additionally, genetic variability across ZIKV strains is not likely to be critical to vaccine design as ZIKV is one serotype, and neutralizing antibodies against one strain protects against the other $(307,308)$.

Innate immune host variability may also modulate disease severity in pregnancy and capacity to induce protective maternal immunity with vaccines. Through the mouse models and in vitro studies of placental explants and primary human trophoblasts it has been found that interferon responses mediate pathogenesis at the maternal-fetal interface. While type I IFN $\alpha / \beta$ inflammatory responses mediate an antiviral response they also cause placental damage in the setting of ZIKV infection, whereas type III IFN $\gamma 1$ restricts $\operatorname{ZIKV~}(309,310)$. In addition, complement may inhibit ZIKV replication in 
an antibody-dependent and independent manner, which may also be altered during pregnancy (311-313). Progress thus far indicates a need to evaluate active and passive vaccination strategies against Zika in a pregnancy model of infection to design optimal candidates.

\section{Vaccine Design Considerations}

All vaccine strategies have an emphasis on prevention of congenital infection, since this defines the primary disease burden. The target population for a vaccine is both male and female populations prior to reproductive age, with a primary goal of a vaccine should be to minimize risk of infection in pregnancy by eliciting protective immunity that is effective in pregnancy. Moreover, vaccinating both men and women will disrupt transmission across populations and reduce likelihood of viral exposure in pregnancy, either through mosquitoes or sexual contact.

A key concern about ZIKV vaccine development is crossreactivity of antibody responses with co-endemic Dengue (DENV) viruses, which are antigenically similar (314). Cross-reactive antibodies that target conserved epitopes across these viruses have the potential to mediate antibodydependent enhancement of subsequent viral infection (315-317). Thus far, cohort studies suggest that prior DENV leads to reduced risk of ZIKV infection $(318,319)$. Moreover, in NHP's prior ZIKV did not adversely impact DENV pathogenesis, though further epidemiologic data is needed $(307,320,321)$. It is known that vaccine-elicited $\operatorname{IgG}$ and flavivirus specific $\operatorname{IgG}$ are efficiently transferred across the placenta, therefore the impact of these antibodies on fetal and neonatal health must be considered in vaccine development (322).

\section{How Close Are We}

Currently, vaccines candidates cannot be assessed for efficacy without on-going transmission. Therefore, the emphasis for vaccine development efforts is on research using animal models and observational cohorts. When Phase II and III efficacy testing is feasible, a successful candidate will have to demonstrate vaccine efficacy in a combination of pregnant and non-pregnant populations. Moreover, as with Ebola vaccine trials, ethical and innovative vaccine trial designs will be necessary in order to assess a vaccine candidate in the context of an outbreak $(323,324)$. Due to the requirement to assess Zika vaccine candidates within outbreak settings, it is possible that evidence for licensure may be derived not only from vaccine trials but also optimal animal models.

\section{CONCLUSION}

Evaluating progress in vaccine development for congenital and perinatal pathogens reveals a varied landscape of priorities based on global disease burden and availability for alternative prophylactic or treatment options. Intensive research investments and progress is characterized by an understanding of the features of protective immunity within animal models and with precedence of clinical vaccine trials that inform on-going research gaps. For Zika, CMV, HSV, and syphilis, the optimal active vaccination would be delivered prior to pregnancy like the rubella and varicella vaccine due to risk of transmission across every stage of pregnancy. These vaccines will need to elicit long lasting sterilizing immunity to prevent infections during pregnancy. Whereas, immunologic approaches for elimination of HIV mother to child transmission have revealed a series of complexities with viral diversity and escape from immunity, leading to increasingly complex passive and active vaccine components that remain to be tested. It is possible that passive maternal immunization could curb vertical transmission rates for ZIKV and HIV, as with Hepatitis B, yet evidence suggests that this will not likely be an effective strategy for CMV and HSV vaccines which may require protective cellular responses in addition to antibody responses. In contrast to these strategies that will be optimal before pregnancy, the GBS vaccine candidates are specifically designed for administration in pregnancy to promote transplacental transfer of antibodies and prevent early and late onset of neonatal disease.

Moreover, vaccine testing approaches also vary. Syphilis and toxoplasma present a unique situation for vaccine development since effective treatment options are available but are rendered ineffective due to implementation challenges. These barriers emphasize the role of public health interventions in promoting pediatric health. Indeed, the availability of a treatment supports vaccine development and testing in seronegative populations as there are well-established standards of care for even the placebo group upon detection of disease. In comparison, a maternal HIV vaccine would only be administered to actively infected individuals and therefore a novel vaccine candidate must demonstrate efficacy in the presence of the ART as standard of care. Whereas for CMV vaccines, these can be tested in seronegative or seropositive populations. Finally, ZIKV vaccines cannot be tested without transmission in the population, which suggests roles for optimal animal models to guide vaccination strategies.

To make further progress on these vaccines for congenital and perinatal infections and protect newborns, it is important to evaluate the vaccine candidate in the relevant setting of mother to child transmission, taking into account the role of pregnancy on immunity and the timing of screening and disease detection. This will allow for more effective translation of vaccine strategies for maternal and newborn health.

\section{AUTHOR CONTRIBUTIONS}

TS and SP substantially contributed to the conception and design of this work and iteratively reviewed sections. TS led the writing process. TS, CO, KL, SV, AN, and SP provided intellectual contributions, offered interpretations and synthesis of the literature, and supported in drafting and revising this work. SP provided approval for publication of this content. All authors contributed to the article and approved the submitted version. 


\section{FUNDING}

This work was supported by grants from the National Institutes of Health to Sallie Permar (R21AI132677 and P01AI129859).

\section{REFERENCES}

1. WHO Western Pacific. (2018). Report on Global Sexually Transmitted Infection Surveillance. Geneva: World Health Organization. Retrieved from: https://www.who.int/publications/i/item/9789241565691

2. Korenromp EL, Rowley J, Alonso M, Mello MB, Saman Wijesooriya N, Guy Mahiané S, et al. Global burden of maternal and congenital syphilis and associated adverse birth outcomes-estimates for 2016 and progress since 2012. PLoS ONE. (2019) 14:e0211720. doi: 10.1371/journal.pone.0211720

3. Yazigi A, De Pecoulas AE, Vauloup-Fellous C, Grangeot-Keros L, Ayoubi JM, Picone O. Fetal and neonatal abnormalities due to congenital rubella syndrome: a review of literature. J Matern Fetal Neonatal Med. (2017) 30:274-8. doi: 10.3109/14767058.2016.1169526

4. McLean HQ, Fiebelkorn AP, Temte JL, Wallace GS. Prevention of measles, rubella, congenital rubella syndrome, and mumps. 2013: summary recommendations of the advisory committee on immunization practices (ACIP). MMWR Recommend Rep. (2013) 62:1-34. Available online at: https://www.cdc.gov/mmwr/preview/mmwrhtml//rr6204a1.htm

5. Plotkin S, Orentstein W, Offit P, Edwards KM. Plotkin's Vaccines. 7th ed. Philadelphia, PA: Elsevier (2017).

6. Control and Prevention of Rubella: Evaluation and Management of Suspected Outbreaks. Rubella in Pregnant Women, and Surveillance for Congenital Rubella Syndrome. (2019) Retrieved from: https://www.cdc.gov/ $\mathrm{mmwr} / \mathrm{preview} / \mathrm{mmwrhtml} / \mathrm{rr} 5012 \mathrm{al}$.htm (accessed March 15, 2020).

7. World Health Organization. Immunization Coverage. (2019) Retrieved from: http://www.who.int/mediacentre/factsheets/fs378/en/ (accessed March 8, 2020).

8. Schillie S, Vellozzi C, Reingold A, Harris A, Haber P, Ward JW, et al. Prevention of hepatitis B virus infection in the United States: recommendations of the advisory committee on immunization practices. MMWR Recommend Rep. (2018) 67:1-31. doi: 10.15585/mmwr.rr6701al

9. WHO Report. Hepatitis B vaccines: WHO position paper - July 2017. Wkly Epidemiol Rec. (2017) 92:369-92. doi: 10.1016/j.vaccine.2017.07.046

10. Lee C, Gong Y, Brok J, Boxall EH, Gluud C. Effect of hepatitis B immunisation in newborn infants of mothers positive for hepatitis $B$ surface antigen: systematic review and meta-analysis. BMJ. (2006) 332:32836. doi: 10.1002/14651858.CD004790.pub2

11. Schillie S, Walker T, Veselsky S, Crowley S, Dusek C, Lazaroff J, et al. Outcomes of infants born to women infected with hepatitis B. Pediatrics. (2015) 135:e1141-7. doi: 10.1542/peds.2014-3213

12. Xu ZY, Liu CB, Francis DP, Purcell RH, Gun ZL, Duan SC, et al. Prevention of perinatal acquisition of hepatitis $\mathrm{B}$ virus carriage using vaccine: preliminary report of a randomized, double-blind placebo-controlled and comparative trial. Pediatrics. (1985) 76:713-8.

13. Stevens CE, Toy PT, Tong MJ, Taylor PE, Vyas GN, Nair PV, et al. Perinatal hepatitis B virus transmission in the United States: prevention by passive-active immunization. JAMA. (1985) 253:17405. doi: 10.1001/jama.1985.03350360066020

14. Marin M, Güris D, Chaves SS, Schmid S, Seward JF. Prevention of varicella: recommendations of the Advisory Committee on Immunization Practices (ACIP). MMW Recommend Rep. (2007) 56:1-40. Available online at: https:// www.cdc.gov/mmwr/preview/mmwrhtml/rr5604a1.htm

15. Wharton M. The epidemiology of varicella-zoster virus infections. Infect Dis Clin North Am. (1996) 10:571-81. doi: 10.1016/S0891-5520(05)70313-5

16. Sauerbrei A, Wutzler P. The congenital varicella syndrome. J Perinatol. (2000) 20:548-54. doi: 10.1038/sj.jp.7200457

17. Marin M. Updated recommendations for use of VariZIG - United States. Am J Transpl. (2013) 13:2765-67. doi: 10.1111/ajt.12477

18. Levin MJ, Duchon JM, Swamy GK, Gershon AA. Varicella zoster immune globulin (VARIZIG) administration up to 10 days after varicella exposure

\section{ACKNOWLEDGMENTS}

We would like to acknowledge Itzayana Miller for timely support with researching group B streptococcus literature. in pregnant women, immunocompromised participants, infants: varicella outcomes safety results from a large, open-label, expended-access program. PLoS ONE. (2019) 14:e0217749. doi: 10.1371/journal.pone.0217749

19. Wutzler P, Bonanni P, Burgess M, Gershon A, Sáfadi MA, Casabona G. Varicella vaccination - the global experience. Expert Rev Vaccines. (2017) 16:833-43. doi: 10.1080/14760584.2017.1343669

20. Blanchard-Rohner G, Eberhardt C. Review of maternal immunisation during pregnancy: focus on pertussis and influenza. Swiss Med Wkly. (2017) 147:w14526. doi: 10.4414/smw.2017.14526

21. Chu HY, Englund JA. Maternal immunization. Birth Defects Res. (2017) 109:379-86. doi: 10.1002/bdra.23547

22. Kachikis A, Englund JA. Maternal immunization: optimizing protection for the mother and infant. J Infect. (2016) 72:S8390. doi: 10.1016/j.jinf.2016.04.027

23. Swamy GK, Heine RP. Vaccinations for pregnant women. Obstet Gynecol. (2015) 125:212-26. doi: 10.1097/AOG.0000000000000581

24. Fouda GG, Martinez DR, Swamy GK, Permar SR. The impact of IgG transplacental transfer on early life immunity. ImmunoHorizons. (2018) 2:14-25. doi: 10.4049/immunohorizons.1700057

25. Malek A, Sager R, Kuhn P, Nicolaides KH, Schneider $H$. Evolution of maternofetal transport of immunoglobulins during human pregnancy. Am J Reprod Immunol. (1996) 36:24855. doi: 10.1111/j.1600-0897.1996.tb00172.x

26. Martinez DR, Fouda GG, Peng X, Ackerman ME, Permar SR. Noncanonical placental Fc receptors: what is their role in modulating transplacental transfer of maternal IgG? PLoS Pathog. (2018) 14:e1007161. doi: 10.1371/journal.ppat.1007161

27. Avanzini MA, Pignatti P, Chirico G, Gasparoni A, Jalil F, Hanson LA. Placental transfer favours high avidity IgG antibodies. Acta Paediatr. (1998) 87:180-5. doi: 10.1111/j.1651-2227.1998.tb00972.x

28. Garty BZ, Ludomirsky A, Danon YL, Peter JB, Douglas SD. Placental transfer of immunoglobulin G subclasses. Clin Diagn Lab Immunol. (1994) 1:6679. doi: 10.1128/CDLI.1.6.667-669.1994

29. Roopenian DC, Akilesh S. FcRn: the neonatal Fc receptor comes of age. Nat Rev Immunol. (2007) 7:715-25. doi: 10.1038/nri2155

30. Jennewein MF, Goldfarb I, Dolatshahi S, Cosgrove C, Noelette FJ, Krykbaeva $\mathrm{M}$, et al. Fc Glycan-mediated regulation of placental antibody transfer. Cell. (2019) 178:202-15.e14. doi: 10.1016/j.cell.2019.05.044

31. Martinez DR, Fong Y, Li SH, Yang F, Jennewein MF, Weiner JA, et al. Fc characteristics mediate selective placental transfer of IgG in HIV-infected women. Cell. (2019) 178:190-201.e11. doi: 10.1016/j.cell.2019.05.046

32. Chilengi R, Simuyandi M, Beach L, Mwila K, Becker-Dreps S, Emperador DM, et al. Association of maternal immunity with rotavirus vaccine immunogenicity in zambian infants. PLoS ONE. (2016) 11:e0150100. doi: 10.1371/journal.pone.0150100

33. Jones C, Pollock L, Barnett SM, Battersby A, Kampmann B. The relationship between concentration of specific antibody at birth and subsequent response to primary immunization. Vaccine. (2014) 32:9961002. doi: 10.1016/j.vaccine.2013.11.104

34. Murphy BR, Olmsted RA, Collins PL, Chanock RM, Prince GA. Passive transfer of respiratory syncytial virus (RSV) antiserum suppresses the immune response to the RSV fusion (F) and large (G) glycoproteins expressed by recombinant vaccinia viruses. J Virol. (1988) 62:390710. doi: 10.1128/JVI.62.10.3907-3910.1988

35. Aaby P, Martins CL, Garly ML, Andersen A, Fisker AB, Claesson MH, et al. Measles vaccination in the presence or absence of maternal measles antibody: Impact on child survival. Clin Infect Dis. (2014) 59:48492. doi: $10.1093 / \mathrm{cid} / \mathrm{ciu} 354$

36. Samb B, Aaby P, Whittle HC, Coll Seck AM, Rahman S, Bennett J, et al. Serologic status and measles attack rates among vaccinated and 
unvaccinated children in rural senegal. Pediatr Infect Dis J. (1995) 14:2039. doi: 10.1097/00006454-199503000-00007

37. Appaiahgari MB, Glass R, Singh S, Taneja S, Rongsen-Chandola T, Bhandari $\mathrm{N}$, et al. Transplacental rotavirus IgG interferes with immune response to live oral rotavirus vaccine ORV-116E in Indian infants. Vaccine. (2014) 32:651-6. doi: 10.1016/j.vaccine.2013.12.017

38. Borràs E, Urbiztondo L, Costa J, Batalla J, Torner N, Plasencia A, et al. Measles antibodies and response to vaccination in children aged less than 14 months: implications for age of vaccination. Epidemiol Infect. (2012) 140:1599-606. doi: 10.1017/S0950268811002184

39. Francis JP, Richmond PC, Pomat WS, Michael A, Keno H, Phuanukoonnon $S$, et al. Maternal antibodies to pneumolysin but not to pneumococcal surface protein a delay early pneumococcal carriage in high-risk papua new guinean infants. Clin Vaccine Immunol. (2009) 16:1633-8. doi: 10.1128/CVI.00247-09

40. Gans H, DeHovitz R, Forghani B, Beeler J, Maldonado Y, Arvin AM. Measles and mumps vaccination as a model to investigate the developing immune system: passive and active immunity during the first year of life. Vaccine. (2003) 21:3398-405. doi: 10.1016/S0264-410X(03)00341-4

41. Garly ML, Balé C, Martins CL, Monteiro M, George E, Kidd M, et al. Measles antibody responses after early two dose trials in guinea-bissau with edmonston-zagreb and schwarz standard-titre measles vaccine: better antibody increase from booster dose of the edmonston-zagreb vaccine. Vaccine. (2001) 19:1951-9. doi: 10.1016/S0264-410X(00)00431-X

42. $\mathrm{Hu} \mathrm{Y}, \mathrm{Wu} \mathrm{Q}, \mathrm{Xu} \mathrm{B}$, Zhou Z, Wang Z, Zhou YH. Influence of maternal antibody against hepatitis $B$ surface antigen on active immune response to hepatitis B vaccine in infants. Vaccine. (2008) 26:60647. doi: 10.1016/j.vaccine.2008.09.014

43. Kurikka S, Käyhty H, Peltola H, Saarinen L, Eskola J, Mäkelä PH. Neonatal immunization: response to haemophilus influenzae type b-tetanus toxoid conjugate vaccine. Pediatrics. (1995) 95:815-22.

44. Letson GW, Shapiro CN, Kuehn D, Gardea C, Welty TK, Krause DS, et al. Effect of maternal antibody on immunogenicity of hepatitis A vaccine in infants. J Pediatr. (2004) 144:327-32. doi: 10.1016/j.jpeds.2003.11.030

45. Piedra PA, Glezen WP, Mbawuike I, Gruber WC, Baxter BD, Boland FJ, et al. Studies on reactogenicity and immunogenicity of attenuated bivalent cold recombinant influenza type A (CRA) and inactivated trivalent influenza virus (TI) vaccines in infants and young children. Vaccine. (1993) 11:71824. doi: 10.1016/0264-410X(93)90255-V

46. Simoes EAF, Padmini B, Steinhoff MC, Jadhav M, John TJ. Antibody response of infants to two doses of inactivated poliovirus vaccine of enhanced potency. Am J Dis Children. (1985) 139:977-80. doi: 10.1001/archpedi.1985.02140120023021

47. Sormunen H, Stenvik M, Eskola J, Hovi T. Age- and dose-intervaldependent antibody responses to inactivated poliovirus vaccine. $J$ Med Virol. (2001) 63:305-10. doi: 10.1002/1096-9071(200104)63:4<305::AIDJMV1006>3.0.CO;2-U

48. Warren RJ, Lepow ML, Bartsch GE, Robbins FC. The relationship of maternal antibody, breast feeding, and age to the susceptibility of newborn infants to infection with attenuated polioviruses. Pediatrics. (1964) 34:4-13.

49. Whittle H, O’Neill K, Marsh V, Aaby P, Hanlon P, Hanlon L, et al. Trial of high-dose edmonston-zagreb measles vaccine in the gambia: antibody response and side-effects. Lancet. (1988) 332:811-4. doi: 10.1016/S0140-6736(88)92781-X

50. CDC. About Cytomegalovirus and Congenital CMV Infection. (2019) Retrieved from: https://www.cdc.gov/cmv/overview.html (accessed November 19, 2019).

51. National CMV Foundation. Newborn Screening. (2019) Retrieved from: https://www.nationalcmv.org/overview/newborn-screening (accessed February 25, 2020).

52. Boppana SB, Ross SA, Shimamura M, Palmer AL, Ahmed A, Michaels MG, et al. Saliva polymerase-chain-reaction assay for cytomegalovirus screening in newborns. N Engl J Med. (2011) 364:2111-8. doi: 10.1056/NEJMoa1006561

53. Kenneson A, Cannon MJ. Review and meta-analysis of the epidemiology of congenital cytomegalovirus (CMV) infection. Rev Med Virol. (2007) 17:253-76. doi: 10.1002/rmv.535

54. Pinninti SG, Ross SA, Shimamura M, Novak Z, Palmer AL, Ahmed A. National Institute on Deafness and Other Communication Disorders CMV and hearing multicenter screening (CHIMES) study.
Comparison of saliva PCR assay versus rapid culture for detection of congenital cytomegalovirus infection. Pediatr Infect Dis J. (2015) 34:536-7. doi: 10.1097/INF.0000000000000609

55. Davis NL, King CC, Kourtis AP. Cytomegalovirus infection in pregnancy. Birth Defects Res. (2017) 109:336-46. doi: 10.1002/bdra.23601

56. Griffiths P, Baraniak I, Reeves M. The pathogenesis of human cytomegalovirus. J Pathol. (2015) 235:288-97. doi: 10.1002/path.4437

57. Nigro G, Anceschi MM, Cosmi EV, Congenital Cytomegalic Disease Collaborating Group. Clinical manifestations and abnormal laboratory findings in pregnant women with primary cytomegalovirus infection. BJOG. (2003) 110:572-7. doi: 10.1046/j.1471-0528.2003.01302.x

58. Dollard SC, Grosse SD, Ross DS. New estimates of the prevalence of neurological and sensory sequelae and mortality associated with congenital cytomegalovirus infection. Rev Med Virol. (2007) 17:35563. doi: 10.1002/rmv.544

59. Ross DS, Dollard SC, Victor M, Sumartojo E, Cannon MJ. The epidemiology and prevention of congenital cytomegalovirus infection and disease: activities of the centers for disease control and prevention workgroup. $J$ Women's Health. (2006) 15:224-9. doi: 10.1089/jwh.2006.15.224

60. Fowler KB, Stagno S, Pass RF, Britt WJ, Alford CA, Boll TJ. The outcome of congenital cytomegalovirus infection in relation to maternal antibody status. N Engl J Med. (1992) 326:663-7. doi: 10.1056/NEJM199203053261003

61. Pass RF, Fowler KB, Boppana SB, Britt WJ, Stagno S. Congenital cytomegalovirus infection following first trimester maternal infection: symptoms at birth and outcome. J Clin Virol. (2006) 35:216-20. doi: 10.1016/j.jcv.2005.09.015

62. Stagno S, Pass RF, Cloud G, Britt WJ, Henderson RE, Walton $\mathrm{PD}$, et al. Primary cytomegalovirus infection in pregnancy: incidence, transmission to fetus, clinical outcome. JAMA. (1986) 256:1904-8. doi: 10.1001/jama.1986.03380140074025

63. Hughes BL, Gyamfi-Bannerman C, Society for Maternal-Fetal Medicine. Diagnosis and antenatal management of congenital cytomegalovirus infection. Am J Obset Gynecol. (2016) 214:B511. doi: 10.1016/j.ajog.2016.02.042

64. Gerna G, Lilleri D. Human cytomegalovirus (HCMV) infection/re-infection: development of a protective HCMV vaccine. New Microbiol. (2019) 42:1-20.

65. Wang C, Zhang X, Bialek S, Cannon MJ. Attribution of congenital cytomegalovirus infection to primary versus non-primary maternal infection. Clin Infect Dis. (2011) 52:e11-3. doi: 10.1093/cid/ciq085

66. Yamamoto AY, Mussi-Pinhata MM, Boppana SB, Novak Z, Wagatsuma VM, Oliveira $P$, et al. Human cytomegalovirus reinfection is associated with intrauterine transmission in a highly cytomegalovirusimmune maternal population. Am J Obstet Gynecol. (2010) 202:297.e1-8. doi: 10.1016/j.ajog.2009.11.018

67. Cytomegalovirus (CMV) - Harvard Health (2019) Retrieved from: https:// www.health.harvard.edu/a_to_z/cytomegalovirus-cmv-a-to-z (accessed January 9, 2020).

68. Bowden RA. Cytomegalovirus infections in transplant patients: methods of prevention of primary cytomegalovirus. Transpl Proc. (1991) 23(Suppl. 3):136-8.

69. Fowler KB, Pass RF. Risk factors for congenital cytomegalovirus infection in the offspring of young women: exposure to young children and recent onset of sexual activity. Pediatrics. (2006) 118:e286-92. doi: 10.1542/peds.2005-1142

70. Lang DJ, Kummer JF. Cytomegalovirus in semen: observations in selected populations. J Infect Dis. (1975) 132:472-3. doi: 10.1093/infdis/132.4.472

71. Reynolds DW, Stagno S, Hosty TS, Tiller M, Alford CA. Maternal cytomegalovirus excretion and perinatal infection. N Engl J Med. (1973) 289:1-5. doi: 10.1056/NEJM197307052890101

72. Bodéus M, Hubinont C, Goubau P. Increased risk of cytomegalovirus transmission in utero during late gestation. Obstet Gynecol. (1999) 93:65860. doi: 10.1016/S0029-7844(98)00538-9

73. Bodéus M, Kabamba-Mukadi B, Zech F, Hubinont C, Bernard P, Goubau P. Human cytomegalovirus in utero transmission: follow-up of 524 maternal seroconversions. J Clin Virol. (2010) 47:201-2. doi: 10.1016/j.jcv.2009.11.009

74. Daiminger A, Bäder U, Enders G. Pre- and periconceptional primary cytomegalovirus infection: risk of vertical transmission and congenital disease. BJOG. (2005) 112:166-72. doi: 10.1111/j.1471-0528.2004.00328.x 
75. Enders G, Daiminger A, Bäder U, Exler S, Enders M. Intrauterine transmission and clinical outcome of 248 pregnancies with primary cytomegalovirus infection in relation to gestational age. J Clin Virol. (2011) 52:244-6. doi: 10.1016/j.jcv.2011.07.005

76. Griffiths PD, Baboonian C. A prospective study of primary cytomegalovirus infection during pregnancy: final report. BJOG. (1984) 91:307-15. doi: 10.1111/j.1471-0528.1984.tb05915.x

77. Picone O, Vauloup-Fellous C, Cordier AG, Guitton S, Senat MV, Fuchs F, et al. A series of 238 cytomegalovirus primary infections during pregnancy: description and outcome. Prenat Diagn. (2013) 33:7518. doi: $10.1002 / \mathrm{pd} .4118$

78. Revello MG, Gerna G. Diagnosis and management of human cytomegalovirus infection in the mother, fetus, newborn infant. Clin Microbiol Rev. (2002) 15:680-715. doi: 10.1128/CMR.15.4.680-715.2002

79. Gindes L, Teperberg-Oikawa M, Sherman D, Pardo J, Rahav G. Congenital cytomegalovirus infection following primary maternal infection in the third trimester. BJOG. (2008) 115:830-5. doi: 10.1111/j.1471-0528.2007.01 651.x

80. Institute of Medicine. Vaccines for the 21st Century: A Tool for Decision Making. Washington, DC: The National Academies Press. (2000) doi: 10.17226/5501

81. Guerra B, Simonazzi G, Puccetti C, Lanari M, Farina A, Lazzarotto T, et al. Ultrasound prediction of symptomatic congenital cytomegalovirus infection. Am J Obstet Gynecol. (2008) 198:380.e1-7. doi: 10.1016/j.ajog.2007.09.052

82. Picone O, Teissier N, Cordier AG, Vauloup-Fellous C, Adle-Biassette H, Martinovic J, et al. Detailed in utero ultrasound description of 30 cases of congenital cytomegalovirus infection. Prenat Diagn. (2014) 34:51824. doi: $10.1002 / \mathrm{pd} .4340$

83. Lazzarotto T, Guerra B, Lanari M, Gabrielli L, Landini MP. New advances in the diagnosis of congenital cytomegalovirus infection. J Clin Virol. (2008) 41:192-7. doi: 10.1016/j.jcv.2007.10.015

84. Donner C, Liesnard C, Brancart F, Rodesch F. Accuracy of amniotic fluid testing before 21 weeks' gestation in prenatal diagnosis of congenital cytomegalovirus infection. Prenat Diagn. (1994) 14:1055-9. doi: 10.1002/pd.1970141108

85. Enders G, Bäder U, Lindemann L, Schalasta G, Daiminger A. Prenatal diagnosis of congenital cytomegalovirus infection in 189 pregnancies with known outcome. Prenat Diagn. (2001) 21:362-77. doi: 10.100 2/pd.59

86. Liesnard C, Donner C, Brancart F, Gosselin F, Delforge ML, Rodesch F. Prenatal diagnosis of congenital cytomegalovirus infection: prospective study of 237 pregnancies at risk. Obstet Gynecol. (2000) 95:8818. doi: 10.1016/S0029-7844(99)00657-2

87. Espiritu MM, Bailey S, Wachtel EV, Mally PV. Utility of routine urine CMV PCR and total serum IgM testing of small for gestational age infants: a single center review. J Perinat Med. (2018) 46:81-6. doi: 10.1515/jpm-2016-0287

88. Krishnamurthy MB, Popiel A, Malhotra A. Screening investigations in small-for-gestational-age near-term and term infants. Eur J Pediatr. (2017) 176:1707-12. doi: 10.1007/s00431-017-3031-8

89. Luck SE, Wieringa JW, Blázquez-Gamero D, Henneke P, Schuster K, Butler K, et al. Congenital cytomegalovirus: a European expert consensus statement on diagnosis and management. Pediatr Infect Dis J. (2017) 36:1205-13. doi: 10.1097/INF.0000000000001763

90. Wei D, Sardesai SR, Barton L. The C in TORCH: a cost-effective alternative to screening small-for-gestational-age infants. Neonatology. (2014) 106:249. doi: 10.1159/000358867

91. Buxmann H, Stackelberg OMV, Schlößer RL, Enders G, Gonser M, MeyerWittkopf $\mathrm{M}$, et al. Use of cytomegalovirus hyperimmunoglobulin for prevention of congenital cytomegalovirus disease: a retrospective analysis. J Perinat Med. (2012) 40:439-46. doi: 10.1515/jpm-2011-0257

92. Nigro G, Adler SP, Parruti G, Anceschi MM, Coclite E, Pezone I, et al. Immunoglobulin therapy of fetal cytomegalovirus infection occurring in the first half of pregnancy-a case-control study of the outcome in children. $J$ Infect Dis. (2012) 205:215-27. doi: 10.1093/infdis/jir718

93. Revello MG, Lazzarotto T, Guerra B, Spinillo A, Ferrazzi E, Kustermann A, et al. A randomized trial of hyperimmune globulin to prevent congenital cytomegalovirus. N Engl J Med. (2014) 370:1316-26. doi: 10.1056/NEJMoa1310214
94. Visentin S, Manara R, Milanese L, Da Roit A, Forner G, Salviato E, et al. Early primary cytomegalovirus infection in pregnancy: maternal hyperimmunoglobulin therapy improves outcomes among infants at 1 year of age. Clin Infect Dis. (2012) 55:497-503. doi: 10.1093/cid/cis423

95. Nigro G, Adler SP, La Torre R, Best AM, Congenital Cytomegalovirus Collaborating Group. Passive immunization during pregnancy for congenital cytomegalovirus infection. $N$ Engl J Med. (2005) 353:1350-62. doi: 10.1056/NEJMoa04 3337

96. Nigro G, Adler SP, Congenital Cytomegalic Disease Collaborating Group. High-dose CMV hyperimmune globulin (HIG) and maternal CMV DNAemia independently predict infant outcome in pregnant women with a primary cytomegalovirus (CMV) infection. Clin Inf Dis. (2019). doi: $10.1093 / \mathrm{cid} / \mathrm{ciz} 1030$

97. American Academy of Pediatrics. Cytomegalovirus infection. In: Kimberlin DW, Brady MT, Jackson MA, Long SS, editors. Red Book: 2015 Report of the Committee on Infectious Diseases. 30th ed. Elk Grove Village, IL: American Academy of Pediatrics (2015). p. 317-21.

98. Practice bulletin No. 151: cytomegalovirus, parvovirus B19, varicella zoster, and toxoplasmosis in pregnancy. Obstet Gynecol. (2015) 125:151025. doi: 10.1097/01.AOG.0000466430.19823.53

99. National CMV Foundation. Overview. (2019) Retrieved from: https://www. nationalcmv.org/overview (accessed February 25, 2020).

100. Griffith BP, McCormick SR, Booss J, Hsiung GD. Inbred guinea pig model of intrauterine infection with cytomegalovirus. Am J Pathol. (1986) 122:112-9.

101. Schleiss MR, McVoy MA. Guinea pig cytomegalovirus: a model for the prevention and treatment of maternal-fetal cytomegalovirus transmission. Future Virol. (2010) 5:207-17. doi: 10.2217/fvl.10.8

102. Inoue $\mathrm{N}$, Abe $\mathrm{M}$, Kobayashi R, Yamada S. Vaccine development for cytomegalovirus. Adv Exp Med Biol. (2018) 1045:27196. doi: 10.1007/978-981-10-7230-7_13

103. Choi KY, El-Hamdi NS, McGregor A. Inclusion of the viral pentamer complex in a vaccine design greatly improves protection against congenital cytomegalovirus in the guinea pig model. J Virol. (2019) 93:e0144219. doi: 10.1128/JVI.01442-19

104. Contreras H, Wussow F, Fernández-Alarcón C, Bierle C, Nguyen J, Diamond DJ, et al. MVA-vectored pentameric complex (PC) and gB vaccines improve pregnancy outcome after guinea pig CMV challenge, but only gB vaccine reduces vertical transmission. Vaccines. (2019) 7:182. doi: 10.3390/vaccines7040182

105. Hashimoto K, Yamada S, Katano H, Fukuchi S, Sato Y, Kato M, et al. Effects of immunization of pregnant guinea pigs with guinea pig cytomegalovirus glycoprotein B on viral spread in the placenta. Vaccine. (2013) 31:3199205. doi: 10.1016/j.vaccine.2013.04.078

106. Schleiss MR, Choi KY, Anderson J, Mash JG, Wettendorff M, Mossman $\mathrm{S}$, et al. Glycoprotein B (gB) vaccines adjuvanted with AS01 or AS02 protect female guinea pigs against cytomegalovirus (CMV) viremia and offspring mortality in a CMV-challenge model. Vaccine. (2014) 32:275662. doi: 10.1016/j.vaccine.2013.07.010

107. Swanson EC, Gillis P, Hernandez-Alvarado N, Fernández-Alarcón C, Schmit M, Zabeli JC, et al. Comparison of monovalent glycoprotein B with bivalent gB/pp65 (GP83) vaccine for congenital cytomegalovirus infection in a guinea pig model: inclusion of GP83 reduces gB antibody response but both vaccine approaches provide equivalent protection against pup mortality. Vaccine. (2015) 33:4013-8. doi: 10.1016/j.vaccine.2015.0 6.019

108. Bialas KM, Tanaka T, Tran D, Varner V, De La Rosa EC, Chiuppesi $\mathrm{F}$, et al. Maternal CD4+ $\mathrm{T}$ cells protect against severe congenital cytomegalovirus disease in a novel nonhuman primate model of placental cytomegalovirus transmission. Proc Natl Acad Sci USA. (2015) 112:1364550. doi: $10.1073 /$ pnas. 1511526112

109. Powers C, Früh K. Rhesus CMV: an emerging animal model for human CMV. Med Microbiol Immunol. (2008) 197:10915. doi: 10.1007/s00430-007-0073-y

110. Nelson CS, Cruz DV, Tran D, Bialas KM, Stamper L, Wu H, et al. Preexisting antibodies can protect against congenital cytomegalovirus infection in monkeys. JCI Insight. (2017) 2:e94002. doi: 10.1172/jci.insight. 94002 
111. Itell HL, Kaur A, Deere JD, Barry PA, Permar SR. Rhesus monkeys for a nonhuman primate model of cytomegalovirus infections. Curr Opin Virol. (2017) 25:126-33. doi: 10.1016/j.coviro.2017.08.005

112. Messaoudi I, Estep R, Robinson B, Wong SW. Nonhuman primate models of human immunology. Antioxid Redox Signal. (2011) 14:21673. doi: 10.1089/ars.2010.3241

113. Fan Q, Nelson CS, Bialas KM, Chiuppesi F, Amos J, Gurley TC, et al. Plasmablast response to primary rhesus cytomegalovirus (CMV) infection in a monkey model of congenital CMV transmission. Clin Vaccine Immunol. (2017) 24:e00510-16. doi: 10.1128/CVI.00510-16

114. Wille PT, Wisner TW, Ryckman B, Johnson DC. Human cytomegalovirus (HCMV) glycoprotein gB promotes virus entry in trans acting as the viral fusion protein rather than as a receptor-binding protein. mBio. (2013) 4:e00332-13. doi: 10.1128/mBio.00332-13

115. Rieder F, Steininger C. Cytomegalovirus vaccine: phase II clinical trial results. Clin Microbiol Infect. (2014) 5:95-102. doi: 10.1111/1469-0691.12449

116. Bernstein DI, Munoz FM, Callahan ST, Rupp R, Wootton SH, Edwards $\mathrm{KM}$, et al. Safety and efficacy of a cytomegalovirus glycoprotein B (gB) vaccine in adolescent girls: a randomized clinical trial. Vaccine. (2016) 34:313-9. doi: 10.1016/j.vaccine.2015.11.056

117. Griffiths PD, Stanton A, McCarrell E, Smith C, Osman M, Harber M, et al. Cytomegalovirus glycoprotein-B vaccine with MF59 adjuvant in transplant recipients: a phase 2 randomised placebo-controlled trial. Lancet. (2011) 377:1256-63. doi: 10.1016/S0140-6736(11)60136-0

118. Baraniak I, Kropff B, Ambrose L, McIntosh M, McLean GR, Pichon S, et al. Protection from cytomegalovirus viremia following glycoprotein B vaccination is not dependent on neutralizing antibodies. Proc Natl Acad Sci USA. (2018) 115:6273-8. doi: 10.1073/pnas.1800224115

119. Bialas KM, Westreich D, Cisneros de la Rosa E, Nelson CS, Kauvar LM, $\mathrm{Fu} \mathrm{M}$, et al. Maternal antibody responses and nonprimary congenital cytomegalovirus infection of HIV-1-exposed infants. J Infect Dis. (2016) 214:1916-23. doi: 10.1093/infdis/jiw487

120. Boppana SB, Britt WJ. Antiviral antibody responses and intrauterine transmission after primary maternal cytomegalovirus infection. J Infect Dis. (1995) 171:1115-21. doi: 10.1093/infdis/171. 5.1115

121. Lilleri D, Kabanova A, Lanzavecchia A, Gerna G. Antibodies against neutralization epitopes of human cytomegalovirus gH/gL/pUL128-130-131 complex and virus spreading may correlate with virus control in vivo. J Clin Immunol. (2012) 32:1324-31. doi: 10.1007/s10875-012-9739-3

122. Lilleri D, Kabanova A, Revello MG, Percivalle E, Sarasini A, Genini E, et al. Fetal human cytomegalovirus transmission correlates with delayed maternal antibodies to $\mathrm{gH} / \mathrm{gL} / \mathrm{pUL} 128-130-131$ complex during primary infection. PLoS ONE. (2013) 8:e59863. doi: 10.1371/journal.pone.0059863

123. Nelson CS, Herold BC, Permar SR. A new era in cytomegalovirus vaccinology: considerations for rational design of next-generation vaccines to prevent congenital cytomegalovirus infection. NPJ Vaccines. (2018) 3:38. doi: 10.1038/s41541-018-0074-4

124. Nelson CS, Huffman T, Jenks JA, De La Rosa EC, Xie G, Vandergrift N, et al. HCMV glycoprotein B subunit vaccine efficacy mediated by nonneutralizing antibody effector functions. Proc Natl Acad Sci USA. (2018) 115:626772. doi: 10.1073/pnas.1800177115

125. Gomes AC, Griffiths PD, Reeves MB. The humoral immune response against the $\mathrm{gB}$ vaccine: lessons learnt from protection in solid organ transplantation. Vaccines. (2019) 7:67. doi: 10.3390/vaccines7030067

126. Harari A, Zimmerli SC, Pantaleo G. Cytomegalovirus (CMV)specific cellular immune responses. Hum Immunol. (2004) 65:500-6. doi: 10.1016/j.humimm.2004.02.012

127. John S, Yuzhakov O, Woods A, Deterling J, Hassett K, Shaw CA, et al. Multi-antigenic human cytomegalovirus mRNA vaccines that elicit potent humoral and cell-mediated immunity. Vaccine. (2018) 36:168999. doi: 10.1016/j.vaccine.2018.01.029

128. Schleiss MR, Lacayo JC, Belkaid Y, McGregor A, Stroup G, Rayner J, et al. Preconceptual administration of an alphavirus replicon UL83 (pp65 homolog) vaccine induces humoral and cellular immunity and improves pregnancy outcome in the guinea pig model of congenital cytomegalovirus infection. J Infect Dis. (2007) 195:789-98. doi: 10.1086/511982
129. Sylwester AW, Mitchell BL, Edgar JB, Taormina C, Pelte C, Ruchti F, et al. Broadly targeted human cytomegalovirus-specific CD4+ and CD8 $+\mathrm{T}$ cells dominate the memory compartments of exposed subjects. J Exp Med. (2005) 202:673-85. doi: 10.1084/jem.20050882

130. Tang J. Cytomegaloviruses: from molecular pathogenesis to intervention. Emerg Infect Dis. (2013) 19:1906. doi: 10.3201/eis1911.131226

131. Sabbaj S, Pass RF, Goepfert PA, Pichon S. Glycoprotein B vaccine is capable of boosting both antibody and CD4 T-cell responses to cytomegalovirus in chronically infected women. J Infect Dis. (2011) 203:1534-41. doi: 10.1093/infdis/jir138

132. Plotkin SA, Wang D, Oualim A, Diamond DJ, Kotton CN, Mossman S, et al. The status of vaccine development against the human cytomegalovirus. $J$ Infect Dis. (2020) 221:S113-22. doi: 10.1093/infdis/jiz447

133. Gantt S, Marchant A, Boppana SB. Higher expectations for a vaccine to prevent congenital cytomegalovirus infection. J Virol. (2018) 92:e0076418. doi: 10.1128/JVI.00764-18

134. Permar SR, Schleiss MR, Plotkin SA. Higher expectations for a vaccine to prevent congenital cytomegalovirus infection. J Virol. (2018) 92:e0077118. doi: 10.1128/JVI.00771-18

135. Permar SR, Schleiss MR, Plotkin SA. Advancing our understanding of protective maternal immunity as a guide for development of vaccines to reduce congenital cytomegalovirus infections. J Virol. (2018) 92:e0003018. doi: 10.1128/JVI.00030-18

136. Schleiss MR. Cytomegalovirus vaccines under clinical development. J Virus Eradic. (2016) 2:198-207. doi: 10.1016/S2055-6640(20)30872-4

137. Nelson CS, Vera Cruz D, Su M, Xie G, Vandergrift N, Pass RF, et al. Intrahost dynamics of human cytomegalovirus variants acquired by seronegative glycoprotein B vaccinees. J Virol. (2019) 93:e0169518. doi: 10.1128/JVI.01695-18

138. Patras KA, Nizet V. Group B streptococcal maternal colonization and neonatal disease: molecular mechanisms and preventative approaches. Front Pediatr. (2018) 6:27. doi: 10.3389/fped.2018.00027

139. Russell NJ, Seale AC, O’Driscoll M, O’Sullivan C, Bianchi-Jassir F, GonzalezGuarin J, et al. Maternal colonization with group b streptococcus and serotype distribution worldwide: systematic review and meta-analyses. Clin Infect Dis. (2017) 65:S100-11. doi: 10.1093/cid/cix658

140. Seale AC, Blencowe H, Bianchi-Jassir F, Embleton N, Bassat Q, Ordi J, et al. Stillbirth with group B streptococcus disease worldwide: systematic review and meta-analyses. Clin Infect Dis. (2017) 65:S12532. doi: 10.1093/cid/cix585

141. WHO. Group B Streptococcus Vaccine Development Technology Roadmap. WHO Report (2017). Retrieved from: http://apps.who.int/bookorders

142. Kohli-Lynch M, Russell NJ, Seale AC, Dangor Z, Tann CJ, Baker CJ, et al. Neurodevelopmental impairment in children after group B streptococcal disease worldwide: systematic review and meta-analyses. Clin Infect Dis. (2017) 65:S190-9. doi: 10.1093/cid/cix663

143. Libster R, Edwards KM, Levent F, Edwards MS, Rench MA, Castagnini LA, et al. Long-term outcomes of group B streptococcal meningitis. Pediatrics. (2012) 130:e8-15. doi: 10.1542/peds.2011-3453

144. Nanduri SA, Petit S, Smelser C, Apostol M, Alden NB, Harrison $\mathrm{LH}$, et al. Epidemiology of invasive early-onset and late-onset group B streptococcal disease in the United States, 2006 to 2015: multistate laboratory and population-based surveillance. JAMA Pediatr. (2019) 173:224-33. doi: 10.1001/jamapediatrics.2018.4826

145. Dahesh S, Hensler ME, Van Sorge NM, Gertz RE, Schrag S, Nizet $\mathrm{V}$, et al. Point mutation in the group $\mathrm{B}$ streptococcal pbp2x gene conferring decreased susceptibility to $\beta$-lactam antibiotics. Antimicrob Agents Chemother. (2008) 52:2915-8. doi: 10.1128/AAC.00461-08

146. Nagano N, Nagano Y, Kimura K, Tamai K, Yanagisawa H, Arakawa Y. Genetic heterogeneity in pbp genes among clinically isolated group B streptococci with reduced penicillin susceptibility. Antimicrob Agents Chemother. (2008) 52:4258-67. doi: 10.1128/AAC.00596-08

147. CDC. Prevention of Perinatal Group B Streptococcal Disease. (2002) Retrieved from: https:/www.cdc.gov/mmwr/preview/mmwrhtml/rr5910al. htm (accessed June 14, 2020).

148. World Health Organisation. WHO Preferred Product Characteristics for Group B Streptococcus Vaccines. WHO Report (2017). 
149. Al-lawama M, AlZaatreh A, Elrajabi R, Abdelhamid S, Badran E. Prolonged rupture of membranes, neonatal outcomes and management guidelines. $J$ Clin Med Res. (2019) 11:360-6. doi: 10.14740/jocmr3809

150. Berardi A, Rossi C, Guidotti I, Vellani G, Lugli L, Reggiani MLB, et al. Factors associated with intrapartum transmission of group B streptococcus. Pediatr Infect Dis J. (2014) 33:1211-5. doi: 10.1097/INF.0000000000000439

151. Centers for Disease Control and Prevention. Active Bacterial Core Surveillance Report Emerging Infections Program Network Group B Streptococcus. Active Bacterial Core Surveillance Report, Emerging Infections Program Report, Group B Streptococcus (2018).

152. Schrag SJ, Verani JR. Intrapartum antibiotic prophylaxis for the prevention of perinatal group B streptococcal disease: experience in the United States and implications for a potential group B streptococcal vaccine. Vaccine. (2013) 31:D20-6. doi: 10.1016/j.vaccine.2012.11.056

153. Nishihara Y, Dangor Z, French N, Madhi S, Heyderman R. Challenges in reducing group B streptococcus disease in African settings. Arch Dis Child. (2017) 102:72-77. doi: 10.1136/archdischild-2016-311419

154. Baltimore RS, Baker CJ, Kasper DL. Antibody to group B streptococcus type III in human sera measured by a mouse protection test. Infect Immun. (1981) 32:56-61. doi: 10.1128/IAI.32.1.56-61.1981

155. Klegerman ME, Boyer KM, Papierniak CK, Gotoff SP. Estimation of the protective level of human IgG antibody to the type-specific polysaccharide of group B streptococcus type Ia. J Infect Dis. (1983) 148:64855. doi: 10.1093/infdis/148.4.648

156. Baker CJ, Carey VJ, Rench MA, Edwards MS, Hillier SL, Kasper $\mathrm{DL}$, et al. Maternal antibody at delivery protects neonates from early onset group B streptococcal disease. J Infect Dis. (2014) 209:7818. doi: 10.1093/infdis/jit549

157. Dangor Z, Kwatra G, Izu A, Adrian P, Cutland CL, Velaphi S, et al. Correlates of protection of serotype-specific capsular antibody and invasive group B streptococcus disease in South African infants. Vaccine. (2015) 33:67939. doi: 10.1016/j.vaccine.2015.10.019

158. Fabbrini M, Rigat F, Rinaudo CD, Passalaqua I, Khacheh S, Creti R, et al. The protective value of maternal group $\mathrm{B}$ streptococcus antibodies: quantitative and functional analysis of naturally acquired responses to capsular polysaccharides and pilus proteins in european maternal sera. Clin Infect Dis. (2016) 63:746-53. doi: 10.1093/cid/ciw377

159. Lin FC, Philips JB III, Azimi PH, Weisman LE, Clark P, Rhoads GG, et al. Level of maternal antibody required to protect neonates against earlyonset disease caused by group B streptococcus type Ia: a multicenter, seroepidemiology study. J Infect Dis. (2001) 184:1022-8. doi: 10.1086/323350

160. Lin FC, Weisman LE, Azimi PH, Philips JB III, Clark P, Regan J, et al. Level of maternal IgG anti-group B streptococcus type III antibody correlated with protection of neonates against early-onset disease caused by this pathogen. $J$ Infect Dis. (2004) 190:928-34. doi: 10.1086/422756

161. Le Doare K, Kampmann B, Vekemans J, Heath PT, Goldblatt $\mathrm{D}$, Nahm $\mathrm{MH}$, et al. Serocorrelates of protection against infant group B streptococcus disease. Lancet Infect Dis. (2019) 19:e162-71. doi: 10.1016/S1473-3099(18)30659-5

162. Kwatra G, Adrian PV, Shiri T, Izu A, Cutland CL, Buchmann EJ, et al. Serotype-specific cell-mediated immunity associated with clearance of homotypic group B streptococcus rectovaginal colonization in pregnant women. J Infect Dis. (2016) 213:1923-6. doi: 10.1093/infdis/jiw056

163. Davies JK, Paoletti LC, McDuffie RS, Madoff LC, Lee S, Eskens J, et al. A randomized trial of conjugated group B streptococcal type Ia vaccine in a rabbit model of ascending infection. Am J Obstet Gynecol. (1999) 181:803-8. doi: 10.1016/S0002-9378(99)70305-4

164. Madoff LC, Paoletti LC, Tai JY, Kasper DL. Maternal immunization of mice with group B streptococcal type III polysaccharide-beta C protein conjugate elicits protective antibody to multiple serotypes. J Clin Invest. (1994) 94:286-92. doi: 10.1172/JCI117319

165. Paoletti LC, Pinel J, Kennedy RC, Kasper DL. Maternal antibody transfer in baboons and mice vaccinated with a group B streptococcal polysaccharide conjugate. J Infect Dis. (2000) 181:653-8. doi: 10.1086/315285

166. Madrid L, Seale AC, Kohli-Lynch M, Edmond KM, Lawn JE, Heath PT, et al. Infant group B streptococcal disease incidence and serotypes worldwide: systematic review and meta-analyses. Clin Infect Dis. (2017) 65:S16072. doi: $10.1093 / \mathrm{cid} / \mathrm{cix} 656$
167. Baker CJ, Paoletti LC, Wessels MR, Guttormsen H, Rench MA, Hickman ME, et al. Safety and immunogenicity of capsular polysaccharide-tetanus toxoid conjugate vaccines for group B streptococcal types Ia and Ib. J Infect Dis. (1999) 179:142-50. doi: 10.1086/314574

168. Baker CJ, Rench MA, Fernandez M, Paoletti LC, Kasper DL, Edwards MSafety S, et al. Safety and immunogenicity of a bivalent group B streptococcal conjugate vaccine for serotypes II and III. J Infect Dis. (2003) 188:66-73. doi: 10.1086/375536

169. Baker CJ, Rench MA, McInnes P. Immunization of pregnant women with group B streptococcal type III capsular polysaccharidetetanus toxoid conjugate vaccine. Vaccine. (2003) 21:346872. doi: 10.1016/S0264-410X(03)00353-0

170. Edwards MS, Lane HJ, Hillier SL, Rench MA, Baker CJ. Persistence of functional antibodies to group B streptococcal capsular polysaccharides following immunization with glycoconjugate vaccines. Vaccine. (2012) 30:4123-6. doi: 10.1016/j.vaccine.2012.04.048

171. Larsson C, Lindroth M, Nordin P, Stålhammar-Carlemalm M, Lindahl G, Krantz I. Association between low concentrations of antibodies to protein $\alpha$ and Rib and invasive neonatal group B streptococcal infection. Arch Dis Child Fetal Neonatal Ed. (2006) 91:F403-8. doi: 10.1136/adc.2005.090472

172. Vekemans J, Crofts J, Baker CJ, Goldblatt D, Heath PT, Madhi $\mathrm{SA}$, et al. The role of immune correlates of protection on the pathway to licensure, policy decision and use of group B streptococcus vaccines for maternal immunization: considerations from World Health Organization consultations. Vaccine. (2019) 37:3190-98. doi: 10.1016/j.vaccine.2019.04.039

173. McQuillan G, Kruszon-Moran D, Flagg EW, Paulose-Ram R. Prevalence of Herpes Simplex Virus Type 1 and Type 2 in Persons Aged 14-49: United States, 2015-2016. NCHS Data Brief (2018), 1-8.

174. Cherpes T, Matthews D, Maryak S. Neonatal herpes simplex virus infection. Herpes Simplex Viruses. (2005) 55:395-410. doi: 10.1097/GRF.0b013e31827146a7

175. Corey L, Wald A. Current concepts: maternal neonatal herpes simplex virus infections. N Engl J Med. (2009) 361:1376-85. doi: 10.1056/NEJMra0807633

176. Kimberlin DW. Herpes simplex virus infections of the newborn. Semin Perinatol. (2007) 31:19-25. doi: 10.1053/j.semperi.2007.01.003

177. Brown ZA, Wald A, Morrow RA, Zeh J, Corey L. Effect of serologic status and cesarean delivery on transmission rates of herpes simplex virus from mother to infant. J Am Med Assoc. (2003) 289:203-9. doi: 10.1001/jama.289.2.203

178. Stone KM, Reiff-Eldridge R, White AD, Cordero JF, Brown Z, Alexander ER, et al. Pregnancy outcomes following systemic prenatal acyclovir exposure: conclusions from the international acyclovir pregnancy registry. 1984-1999. Birth Defects Res A Clin Mol Teratol. (2004) 70:2017. doi: 10.1002/bdra.20013

179. Watts DH, Brown ZA, Money D, Selke S, Huang ML, Sacks SL, et al. A double-blind, randomized, placebo-controlled trial of acyclovir in late pregnancy for the reduction of herpes simplex virus shedding and cesarean delivery. Am J Obstet Gynecol. (2003) 188:836-43. doi: 10.1067/mob.2003.185

180. Gantt S, Muller WJ. The immunologic basis for severe neonatal herpes disease and potential strategies for therapeutic intervention. Clin Dev Immunol. (2013) 2013:369172. doi: 10.1155/2013/369172

181. Sheffield JS, Hollier LM, Hill JB, Stuart GS, Wendel GD. Acyclovir prophylaxis to prevent herpes simplex virus recurrence at delivery: a systematic review. Obstet Gynecol. (2003) 102:1396403. doi: 10.1097/00006250-200312000-00030

182. James SH, Sheffield JS, Kimberlin DW. Mother-to-child transmission of herpes simplex virus. J Pediatr Infect Dis Soc. (2014) 3:19-23. doi: 10.1093/jpids/piu050

183. Kimberlin DW, Lin CY, Jacobs RF, Powell DA, Corey L, Gruber WC, et al. Safety and efficacy of high-dose intravenous acyclovir in the management of neonatal herpes simplex virus infections. Pediatrics. (2001) 108:2308. doi: 10.1542/peds.108.2.230

184. Kimura H, Futamura M, Ito Y, Ando Y, Hara S, Sobajima H, et al. Relapse of neonatal herpes simplex virus infection. Arch Dis Child Fetal Neonatal Ed. (2003) 88:F483-6. doi: 10.1136/fn.88.6.F483

185. Malm G, Forsgren M, Azazi M, El Persson A. A follow-up study of children with neonatal herpes simplex virus infections with particular 
regard to late nervous disturbances. Acta Paediatr. (1991) 80:22634. doi: 10.1111/j.1651-2227.1991.tb11838.x

186. Whitley R, Arvin A, Prober C, Corey L, Burchett S, Plotkin S, et al. Predictors of morbidity and mortality in neonates with herpes simplex virus infections. N Engl J Med. (1991) 324:450-4. doi: 10.1056/NEJM199102143240704

187. Dudley KL, Bourne N, Milligan GN. Immune protection against HSV-2 in B-cell-deficient mice. Virology. (2000) 270:454-63. doi: 10.1006/viro.200 0.0298

188. Eriksson K, Harandi AM, Svennerholm B, Holmgren J. Differential roles of $B$ cells and IFN- $\gamma$-secreting CD4+ T cells in innate and adaptive immune control of genital herpes simplex virus type 2 infection in mice. J Gen Virol. (2001) 82:845-53. doi: 10.1099/0022-1317-82-4-845

189. Peng T, Zhu J, Phasouk K, Koelle DM, Wald A, Corey L. An effector phenotype of CD8+ $\mathrm{T}$ cells at the junction epithelium during clinical quiescence of herpes simplex virus 2 infection. J Virol. (2012) 86:10587-96. doi: 10.1128/JVI.012 37-12

190. Kao CM, Goymer J, Loh LN, Mahant A, Aschner CB, Herold BC. Murine model of maternal immunization demonstrates protective role for antibodies that mediate antibody-dependent cellular cytotoxicity in protecting neonates from herpes simplex virus type 1 and type 2. J Infect Dis. (2019) 221:72938. doi: 10.1093/infdis/jiz521

191. Gallichan WS, Rosenthal KL. Long-term immunity and protection against herpes simplex virus type 2 in the murine female genital tract after mucosal but not systemic immunization. J Infect Dis. (1998) 177:115561. doi: $10.1086 / 515286$

192. Milligan GN, Bernstein DI. Generation of humoral immune responses against herpes simplex virus type 2 in the murine female genital tract. Virology. (1995) 206:234-41. doi: 10.1016/S0042-6822(95)80038-7

193. Burn C, Ramsey N, Garforth SJ, Almo S, Jacobs WR, Herold BC. A herpes simplex virus (HSV)-2 single-cycle candidate vaccine deleted in glycoprotein D protects male mice from lethal skin challenge with clinical isolates of HSV-1 and HSV-2. J Infect Dis. (2018) 217:754-8. doi: 10.1093/infdis/jix628

194. Koelle DM, Corey L. Herpes simplex: insights on pathogenesis and possible vaccines. Annu Rev Med. (2008) 59:38195. doi: 10.1146/annurev.med.59.061606.095540

195. Bernstein DI, Cardin RD, Bravo FJ, Awasthi S, Lu P, Pullum DA, et al. Successful application of prime and pull strategy for a therapeutic HSV vaccine. NPJ Vaccines. (2019) 4:33. doi: 10.1038/s41541-019-0129-1

196. Shin H, Iwasaki A. A vaccine strategy that protects against genital herpes by establishing local memory T cells. Nature. (2012) 491:4637. doi: $10.1038 /$ nature 11522

197. Dasgupta G, BenMohamed L. Of mice and not humans: How reliable are animal models for evaluation of herpes CD8 +-T cell-epitopesbased immunotherapeutic vaccine candidates? Vaccine. (2011) 29:582436. doi: 10.1016/j.vaccine.2011.06.083

198. Truong NR, Smith JB, Sandgren KJ, Cunningham AL. Mechanisms of immune control of mucosal HSV infection: a guide to rational vaccine design. Front Immunol. (2019) 10:373. doi: 10.3389/fimmu.2019. 00373

199. Belshe RB, Leone PA, Bernstein DI, Wald A, Levin MJ, Stapleton JT, et al. Efficacy results of a trial of a herpes simplex vaccine. N Engl J Med. (2012) 366:34-43. doi: 10.1056/NEJMoa1103151

200. Belshe RB, Heineman TC, Bernstein DI, Bellamy AR, Ewell M, Van Der Most $\mathrm{R}$, et al. Correlate of immune protection against HSV-1 genital disease in vaccinated women. J Infect Dis. (2014) 209:828-36. doi: 10.1093/infdis/jit651

201. Corey L, Langenberg AGM, Ashley R, Sekulovich RE, Izu AE, Douglas $J M$, et al. Recombinant glycoprotein vaccine for the prevention of genital HSV-2 infection: two randomized controlled trials. J Am Med Assoc. (1999) 282:331-40. doi: 10.1001/jama.282.4.331

202. Dropulic LK, Oestreich MC, Pietz HL, Laing KJ, Hunsberger S, Lumbard K, et al. A randomized, double-blinded, placebo-controlled, phase 1 study of a replication-defective herpes simplex virus (HSV) type 2 vaccine, HSV529, in adults with or without HSV infection. J Infect Dis. (2019) 220:9901000. doi: 10.1093/infdis/jiz225

203. Dutton JL, Woo WP, Chandra J, Xu Y, Li B, Finlayson N, et al. An escalating dose study to assess the safety, tolerability and immunogenicity of a herpes simplex virus DNA vaccine, COR-1. Hum Vaccines Immunother. (2016) 12:3079-88. doi: 10.1080/21645515.2016.1221872

204. Awasthi S, Huang J, Shaw C, Friedman HM. Blocking herpes simplex virus 2 glycoprotein E immune evasion as an approach to enhance efficacy of a trivalent subunit antigen vaccine for genital herpes. J Virol. (2014) 88:842132. doi: 10.1128/JVI.01130-14

205. Odegard JM, Flynn PA, Campbell DJ, Robbins SH, Dong L, Wang $\mathrm{K}$, et al. A novel HSV-2 subunit vaccine induces GLA-dependent $\mathrm{CD} 4$ and $\mathrm{CD} 8 \mathrm{~T}$ cell responses and protective immunity in mice and guinea pigs. Vaccine. (2016) 34:101-9. doi: 10.1016/j.vaccine.2015.1 0.137

206. UNAIDS. Global HIV and AIDS Statistics - 2019 Fact Sheet. (2019) Retrieved from: https://www.unaids.org/en/resources/fact-sheet (accessed March 15, 2020).

207. HIV/AIDS (2019). Retrieved from: https://www.who.int/news-room/factsheets/detail/hiv-aids (accessed March 15, 2020).

208. Barlow-Mosha L, Eckard AR, McComsey GA, Musoke PM. Metabolic complications and treatment of perinatally HIV-infected children and adolescents. J Int AIDS Soc. (2013) 16:18600. doi: 10.7448/IAS.16.1.18600

209. World Health Organization. Consolidated Guidelines on HIV Testing Services For a Changing Epidemic. WHO Policy Brief (2019) Retrieved from: https:// apps.who.int/iris/bitstream/handle/10665/179870/9789241508926_eng.pdf? sequence $=1$ LB-0ojl

210. World Health Organization (WHO). Consolidated Guidelines on the Use of Antiretroviral Drugs for Treating and Preventing HIV Infection. 2nd ed. Geneva: World Health Organization (2016). Retrieved from: https://www. who.int/hiv/pub/arv/arv-2016/en/

211. Newell ML. Current issues in the prevention of mother-to-child transmission of HIV-1 infection. Trans $R$ Soc Trop Med Hyg. (2006) 100:1-5. doi: 10.1016/j.trstmh.2005.05.012

212. Permar SR, Fong Y, Vandergrift N, Fouda GG, Gilbert P, Parks R, et al. Maternal HIV-1 envelope-specific antibody responses and reduced risk of perinatal transmission. J Clin Invest. (2015) 125:2702-6. doi: 10.1172/JCI8 1593

213. Mutucumarana CP, Eudailey J, McGuire EP, Vandergrift N, Tegha G, Chasela $\mathrm{C}$, et al. Maternal humoral immune correlates of peripartum transmission of clade C HIV-1 in the setting of peripartum antiretrovirals. Clin Vaccine Immunol. (2017) 24:e00062-17. doi: 10.1128/CVI.00062-17

214. Diomede L, Nyoka S, Pastori C, Scotti L, Zambon A, Sherman G, et al. Passively transmitted gp41 antibodies in babies born from HIV-1 subtype C-seropositive women: correlation between fine specificity and protection. $J$ Virol. (2012) 86:4129-38. doi: 10.1128/JVI.06359-11

215. Hompe ED, Jacobson DL, Eudailey JA, Butler K, Edwards W, Pollara J, et al. Maternal humoral immune responses do not predict postnatal HIV-1 transmission risk in antiretroviral-treated mothers from the IMPAACT PROMISE study. MSphere. (2019) 4:e00716-19. doi: 10.1128/mSphere.00716-19

216. Mabuka J, Nduati R, Odem-Davis K, Peterson D, Overbaugh J. HIV-specific antibodies capable of ADCC are common in breastmilk and are associated with reduced risk of transmission in women with high viral loads. PLoS Pathog. (2012) 8:e1002739. doi: 10.1371/journal.ppat.1002739

217. Ahmad N, Baroudy BM, Baker RC, Chappey C. Genetic analysis of human immunodeficiency virus type 1 envelope $\mathrm{V} 3$ region isolates from mothers and infants after perinatal transmission. J Virol. (1995) 69:100112. doi: 10.1128/JVI.69.2.1001-1012.1995

218. Kumar A, Smith CEP, Giorgi EE, Eudailey J, Martinez DR, Yusim K, et al. Infant transmitted/founder HIV-1 viruses from peripartum transmission are neutralization resistant to paired maternal plasma. PLoS Pathog. (2018) 14:e1006944. doi: 10.1371/journal.ppat.1006944

219. Wu X, Parast AB, Richardson BA, Nduati R, John-Stewart G, Mbori-Ngacha $D$, et al. Neutralization escape variants of human immunodeficiency virus type 1 are transmitted from mother to infant. J Virol. (2006) 80:83544. doi: 10.1128/JVI.80.2.835-844.2006

220. Ghulam-Smith M, Olson A, White LF, Chasela CS, Ellington SR, Kourtis AP, et al. Maternal but not infant anti-HIV-1 neutralizing antibody response associates with enhanced transmission and infant morbidity. mBio. (2017) 8:e1373-17. doi: 10.1128/mBio.01373-17 
221. Martinez DR, Tu JJ, Kumar A, Mangold JF, Mangan RJ, Goswami R, et al. Maternal broadly neutralizing antibodies can select for neutralizationresistant, infant-transmitted/founder HIV variants. mBio. (2020) 11:e0017620. doi: 10.2139/ssrn.3381953

222. Van Rompay KK, Berardi CJ, Dillard-Telm S, Tarara RP, Canfield DR, Valverde CR, et al. Passive immunization of newborn rhesus macaques prevents oral simian immunodeficiency virus infection. J Infect Dis. (1998) 177:1247-59. doi: 10.1086/515270

223. Baba TW, Liska V, Hofmann-Lehmann R, Vlasak J, Xu W, Ayehunie S, et al. Human neutralizing monoclonal antibodies of the IgG1 subtype protect against mucosal simian-human immunodeficiency virus infection. Nat Med. (2000) 6:200-6. doi: 10.1038/72309

224. Hessell AJ, Jaworski JP, Epson E, Matsuda K, Pandey S, Kahl C, et al. Early short-term treatment with neutralizing human monoclonal antibodies halts SHIV infection in infant macaques. Nat Med. (2016) 22:3628. doi: $10.1038 / \mathrm{nm} .4063$

225. Onyango-Makumbi C, Omer SB, Mubiru M, Moulton LH, Nakabiito C, Musoke P, et al. Safety and efficacy of HIV hyperimmune globulin for prevention of mother-to-child HIV transmission in HIV-1infected pregnant women and their infants in Kampala, Uganda (HIVIGLOB/NVP STUDY). J Acquir Immune Defic Syndr. (2011) 58:399-407. doi: 10.1097/QAI.0b013e31822f8914

226. Stiehm ER, Lambert JS, Mofenson LM, Bethel J, Whitehouse J, Nugent R, et al. Efficacy of zidovudine and human immunodeficiency virus (HIV) hyperimmune immunoglobulin for reducing perinatal HIV transmission from HIV-infected women with advanced disease: results of Pediatric AIDS clinical trials group protocol 185. J Infect Dis. (1999) 179:56775. doi: $10.1086 / 314637$

227. Wright PF, Lambert JS, Gorse GJ, Hsieh RH, McElrath MJ, Weinhold $\mathrm{K}$, et al. Immunization with envelope $\mathrm{MN}$ rgp120 vaccine in human immunodeficiency virus-infected pregnant women. J Infect Dis. (1999) 180:1080-8. doi: 10.1086/314985

228. Andrabi R, Bhiman JN, Burton DR. Strategies for a multi-stage neutralizing antibody-based HIV vaccine. Curr Opin Immunol. (2018) 53:14351. doi: 10.1016/j.coi.2018.04.025

229. Ditse Z, Muenchhoff M, Adland E, Jooste P, Goulder P, Moore PL, et al. HIV1 subtype $\mathrm{C}$-infected children with exceptional neutralization breadth exhibit polyclonal responses targeting known epitopes. J Virol. (2018) 92:e0087818. doi: 10.1128/JVI.00878-18

230. Fouda GG, De Paris K, Levy O, Marchant A, Gray G, Permar S, et al. Immunological mechanisms of inducing HIV immunity in infants. In Vaccine. (2020) 38:411-15. doi: 10.1016/j.vaccine.2019.11.011

231. Goo L, Chohan V, Nduati R, Overbaugh J. Early development of broadly neutralizing antibodies in HIV-1-infected infants. Nat Med. (2014) 20:6558. doi: 10.1038/nm.3565

232. Muenchhoff M, Adland E, Karimanzira O, Crowther C, Pace M, Csala A, et al. Nonprogressing HIV-infected children share fundamental immunological features of nonpathogenic SIV infection. Sci Transl Med. (2016) 8:358ra125. doi: 10.1126/scitranslmed.aag1048

233. NIH: National Institute of Allergy and Infectious Diseases. Experimental HIV Vaccine Regimen Ineffective in Preventing HIV | (2019) Retrieved from: https://www.niaid.nih.gov/news-events/experimental-hiv-vaccineregimen-ineffective-preventing-hiv (accessed March 15, 2020).

234. Montoya JG, Liesenfeld O. Toxoplasmosis. Lancet. (2004) 363:196576. doi: 10.1016/S0140-6736(04)16412-X

235. Robert-Gangneux F, Dardé M-L. Epidemiology of and diagnostic strategies for toxoplasmosis. Clin Microbiol Rev. (2012) 25:26496. doi: 10.1128/CMR.05013-11

236. Black MW, Boothroyd JC. Lytic cycle of Toxoplasma gondii. Microbiol Mol Biol Rev. (2000) 64:607-23. doi: 10.1128/MMBR.64.3.607-623.2000

237. Saadatnia G, Golkar M. A review on human toxoplasmosis. Scand J Infect Dis. (2012) 44:805-14. doi: 10.3109/00365548.2012.693197

238. Cook AJ, Gilbert RE, Buffolano W, Zufferey J, Petersen E, Jenum PA, et al. Sources of toxoplasma infection in pregnant women: European multicentre case-control study. BMJ. (2000) 321:142. doi: 10.1136/bmj.321.7254.142

239. Dunay IR, Gajurel K, Dhakal R, Liesenfeld O, Montoya JG. Treatment of toxoplasmosis: historical perspective, animal. Clin Microbiol Infect. (2018) 31:1-33. doi: 10.1128/CMR.00057-17
240. Montoya JG, Remington JS. Management of Toxoplasma gondii infection during pregnancy. Clin Infect Dis. (2008) 47:554-66. doi: 10.1086/590149

241. Yarovinsky F. Innate immunity to Toxoplasma gondii infection. Nat Rev Immunol. (2014) 14:109-21. doi: 10.1038/nri3598

242. Dupont CD, Christian DA, Hunter CA. Immune response and immunopathology during toxoplasmosis ${ }^{1}$. Semin Immunopathol. (2012) 34:793-813. doi: 10.1007/s00281-012-0339-3

243. Aliberti J, Corn RA, Bafica A, Machado FS, Liu C-H, et al. Cutting edge: dendritic cells are essential for in vivo IL-12 production and development of resistance against Toxoplasma gondii infection in mice. J Immunol. (2006) 177:31-5. doi: 10.4049/jimmunol.177.1.31

244. Luft BJ, Remington JS. Toxoplasmic encephalitis in AIDS. Clin Infect Dis. (1992) 15:211-22. doi: 10.1093/clinids/15.2.211

245. Johnson LL, Sayles PC. Deficient humoral responses underlie susceptibility to Toxoplasma gondii in CD4-deficient mice. Infect Immun. (2002) 70:18591. doi: 10.1128/IAI.70.1.185-191.2002

246. Sacks DL, Peters NC, Bethony JM. Vaccines against parasites. In: Bloom BR, Lambert PH, editors. The Vaccine Book, 2nd ed. Cambridge, MA: Academic Press (2016). p. 331-60.

247. Henriquez FL, Woods S, Cong H, McLeod R, Roberts CW. Immunogenetics of toxoplasma gondii informs vaccine design. Trends Parasitol. (2010) 26:550-5. doi: 10.1016/j.pt.2010.06.004

248. Avelino MM, Amaral WN, Rodrigues IM, Rassi AR, Gomes MB, Costa TL, et al. Congenital toxoplasmosis and prenatal care state programs. BMC Infect Dis. (2014) 14:33. doi: 10.1186/1471-2334-14-33

249. Wang JL, Zhang NZ, Li TT, He JJ, Elsheikha HM, Zhu XQ. Advances in the development of anti-Toxoplasma gondii vaccines: challenges, opportunities, and perspectives. Trends Parasitol. (2019) 35:239-53. doi: 10.1016/j.pt.2019.01.005

250. Innes EA, Bartley PM, Rocchi M, Benavidas-Silvan J, Burrells A, Hotchkiss E, et al. Developing vaccines to control protozoan parasites in ruminants: dead or alive? Vet Parasitol. (2011) 180:155-63. doi: 10.1016/j.vetpar.2011.05.036

251. Karanja-Lumumba T, Mugambi J, Wesonga F. Adoption of east coast fever vaccine among smallholder dairy farmers in kenya: the case of North Rift Kenya. East Afr Agric For J. (2015) 81:34-9. doi: 10.1080/00128325.2015.1040646

252. Wijesooriya S, Rochat RW, Kamb ML, Turlapati P, Temmerman M, Broutet $\mathrm{N}$, et al. Global burden of maternal and congenital syphilis in 2008 and 2012: a health systems modelling study. Lancet Global Health. (2016) 4:E52533. doi: 10.1016/S2214-109X(16)30135-8

253. Stamm LV. Global challenge of antibiotic-resistant Treponema pallidum. Antimicrob Agents Chemother. (2010) 54:583-9. doi: 10.1128/AAC.01095-09

254. Stafford IA, Sánchez PJ, Stoll BJ. Ending congenital syphilis. JAMA. (2019) 322:2073-4. doi: 10.1001/jama.2019.17031

255. Cameron CE. Syphilis vaccine development: requirements, challenges and opportunities. Sex Transm Dis. (2018) 45:S1719. doi: 10.1097/OLQ.0000000000000831

256. Rubin R. Why are mothers still passing syphilis to their babies? JAMA. (2019) 321:729-31. doi: 10.1001/jama.2018.20843

257. Warren HP, Cramer R, Kidd S, Leichliter JS. State requirements for prenatal syphilis screening in the United States, 2016. Matern Child Health J. (2018) 22:1227-32. doi: 10.1007/s10995-0182592-0

258. Kojima N, Klausner JD. An update on the global epidemiology of syphilis. Curr Epidemiol Rep. (2018) 5:24-38. doi: 10.1007/s40471-018-0138-z

259. Anugulruengkitt S, Yodkitudomying C, Sirisabya A, Chitsinchayakul T, Jantarabenjakul W, Chaithongwongwatthana S, et al. Gaps to eliminate congenital syphilis in a tertiary care center in Thailand. Pediatr Int. (2019) 62:330-6. doi: 10.1111/ped.14132

260. Taylor MM, Nurse-Findlay S, Zhang X, Hedman L, Kamb ML, Broutet $\mathrm{N}$, et al. Estimating benzathine penicillin need for the treatment of pregnant women diagnosed with syphilis during antenatal care in high-morbidity countries. PLoS ONE. (2016) 11:e0159483. doi: 10.1371/journal.pone.0159483

261. Radolf JD, Deka RK, Anand A, Šmajs D, Norgard MV, Yang XF. Treponema pallidum, the syphilis spirochete: making a living as a stealth pathogen HHS public access. Nat Rev Microbiol. (2016) 14:74459. doi: $10.1038 /$ nrmicro.2016.141 
262. Lukehart SA, Baker-Zander SA, Sell S. Characterization of lymphocyte responsiveness in early experimental syphilis. I. In vitro response to mitogens and Treponema pallidum antigens. J Immunol. (1980) 124:454-60.

263. Carlson JA, Dabiri G, Cribier B, Sell S, Physician R. THE immunopathobiology of syphilis: the manifestations and course of syphilis are determined by the level of delayed-type hypersensitivity. Am J Dermatopathol. (2011) 33:433-60. doi: 10.1097/DAD.0b013e3181e8b587

264. Cameron CE, Lukehart SA, Castro C, Molini B, Godornes C, Van Voorhis WC. Opsonic potential, protective capacity, and sequence conservation of the Treponema pallidum subspecies pallidum Tp92. J Infect Dis. (2000) 181:1401-13. doi: 10.1086/315399

265. Edmondson DG, Hu B, Norris SJ. Long-term in vitro culture of the syphilis spirochete Treponema pallidum subsp. Pallidum MBio. (2018) 9:e0115318. doi: 10.1128/mBio.01153-18

266. Metzger M, Michalska E, Podwinska J, Smogor W, Miller JN, Turner TB, et al. Zurich, world health organization. Acta Pathol Microbiol Scand. (1957) 45:627.

267. Radolf JD, Kumar S. The Treponema pallidum outer membrane. Curr Top Microbiol Immunol. (2018) 415:1-38. doi: 10.1007/82_2017_44

268. Polonio CM, Longo De Freitas C, Zanluqui NG, Pierre J, Peron S. Zika virus congenital syndrome: experimental models and clinical aspects. $J$ Venom Anim Toxins Incl Trop Dis. (2017) 23:41. doi: 10.1186/s40409-017-0131-x

269. Rasmussen SA, Jamieson DJ, Honein MA, Petersen LR. Zika virus and birth defects - reviewing the evidence for causality. $N$ Engl J Med. (2016) 374:1981-7. doi: 10.1056/NEJMsr 160 4338

270. Reynolds MR, Jones AM, Petersen EE, Lee EH, Rice ME, Bingham A, et al. Vital signs: update on zika virus-associated birth defects and evaluation of all U.S. infants with congenital zika virus exposure - U.S. zika pregnancy registry 2016. MMWR Morb Mortal Wkly Rep. (2017) 66:36673. doi: $10.15585 / \mathrm{mmwr} . \mathrm{mm} 6613 \mathrm{e} 1$

271. Brasil P, Pereira JP, Moreira ME, Ribeiro Nogueira RM, Damasceno L, Wakimoto $\mathrm{M}$, et al. Zika virus infection in pregnant women in rio de janeiro. N Engl J Med. (2016) 375:2321-34. doi: 10.1056/NEJMoa1602412

272. Mlakar J, Korva M, Tul N, Popović M, Poljšak-Prijatelj M, Mraz J, et al. Zika virus associated with microcephaly. N Engl J Med. (2016) 374:9518. doi: 10.1056/NEJMoa1600651

273. Foy BD, Kobylinski KC, Foy JLC, Blitvich BJ, da Rosa AT, Haddow AD, et al. Probable non-vector-borne transmission of zika virus, Colorado, USA. Emerg Infect Dis. (2011) 17:880-2. doi: 10.3201/eid1705.101939

274. Duffy MR, Chen TH, Hancock WT, Powers AM, Kool JL, Lanciotti RS, et al. Zika virus outbreak on Yap Island, federated states of Micronesia. $N$ Engl J Med. (2009) 360:2536-43. doi: 10.1056/NEJMoa0805715

275. Adams Waldorf KM, Nelson BR, Stencel-Baerenwald JE, Studholme C, Kapur RP, Armistead B, et al. Congenital zika virus infection as a silent pathology with loss of neurogenic output in the fetal brain. Nat Med. (2018) 24:368-74. doi: 10.1038/nm.4485

276. Nielsen-Saines K, Brasil P, Kerin T, Vasconcelos Z, Gabaglia CR, Damasceno $\mathrm{L}$, et al. Delayed childhood neurodevelopment and neurosensory alterations in the second year of life in a prospective cohort of ZIKV-exposed children. Nat Med. (2019) 25:1213-7. doi: 10.1038/s41591-019-0496-1

277. Centers for Disease Control and Prevention. Transcript for CDC Telebriefing: Zika Summit Press Conference. (2016) Retrieved from https://www.cdc.gov/ media/releases/2016/t0404-zika-summit.html. (accessed October 10, 2019)

278. Buechler CR, Bailey AL, Weiler AM, Barry GL, Breitbach ME, Stewart LM, et al. Seroprevalence of zika virus in wild African green monkeys and baboons. mSphere. (2016) 2:e00932-16. doi: 10.1128/mSphere.00392-16

279. Moreira-Soto A, Carneiro I, de O, Fischer C, Feldmann M, Kümmerer $\mathrm{BM}$, et al. Limited evidence for infection of urban and periurban nonhuman primates with zika and chikungunya viruses in Brazil. MSphere. (2018) 3:e00523-17. doi: 10.1128/mSphere.005 23-17

280. Terzian ACB, Zini N, Sacchetto L, Rocha RF, Parra MCP, Del Sarto JL, et al. Evidence of natural zika virus infection in neotropical non-human primates in Brazil. Sci Rep. (2018) 8:16034. doi: 10.1038/s41598-018-34423-6

281. Castro MC, Han QC, Carvalho LR, Victora CG, França GVA. Implications of zika virus and congenital zika syndrome for the number of live births in Brazil. Proc Natl Acad Sci U S A. (2018) 115:6177-82. doi: 10.1073/pnas.1718476115

282. Diaz-Quijano FA, Pelissari DM, Chiavegatto Filho ADP. Zika-associated microcephaly epidemic and birth rate reduction in Brazilian cities. Am J Public Health. (2018) 108:514-6. doi: 10.2105/AJPH.2017.304260

283. Oduyebo T, Polen KD, Walke HT, Reagan-Steiner S, Lathrop E, Rabe IB, et al. Update: interim guidance for health care providers caring for pregnant women with possible zika virus exposure - United States (including territories) US, July 2017. MMWR Morbi Mortal Wkly Rep. (2017) 66:78193. doi: 10.15585/mmwr.mm6629e1

284. Dick OB, San Martín JL, Montoya RH, Del Diego J, Zambrano B, Dayan GH. Review: the history of dengue outbreaks in the Americas. Am J Trop Med Hygiene. (2012) 87:584-93. doi: 10.4269/ajtmh.2012.11-0770

285. Lozier MJ, Rosenberg ES, Doyle K, Adams L, Klein L, Muñoz-Jordan J, et al. Prolonged detection of zika virus nucleic acid among symptomatic pregnant women: a cohort study. Clin Infect Dis. (2018) 67:6247. doi: 10.1093/cid/ciy209

286. Paz-Bailey G, Rosenberg ES, Doyle K, Munoz-Jordan J, Santiago GA, Klein L, et al. Persistence of zika virus in body fluids - final report. N Engl J Med. (2018) 379:1234-43. doi: 10.1056/NEJMoa1613108

287. Russell K, Oliver SE, Lewis L, Barfield WD, Cragan J, MeaneyDelman D, et al. Update: interim guidance for the evaluation and management of infants with possible congenital zika virus infection United States, August 2016. MMWR Morb Mortal Wkly Rep. (2016) 65:8708. doi: 10.15585/mmwr.mm6533e2

288. Mann TZ, Haddad LB, Williams TR, Hills SL, Read JS, Dee DL, et al. Breast milk transmission of flaviviruses in the context of zika virus: a systematic review. Paediatr Perinatal Epidemiol. (2018) 32:35868. doi: $10.1111 /$ ppe. 12478

289. Dudley DM, Aliota MT, Mohr EL, Weiler AM, Lehrer-Brey G, Weisgrau $\mathrm{KL}$, et al. A rhesus macaque model of Asian-lineage zika virus infection. Nat Commun. (2016) 7:12204. doi: 10.1038/ncomms12204

290. Julander JG, Siddharthan V. Small-animal models of zika virus. J Infect Dis. (2017) 216:S919-27. doi: 10.1093/infdis/jix465

291. Katzelnick LC, Harris E. The use of longitudinal cohorts for studies of dengue viral pathogenesis and protection. Curr Opin Virol. (2018) 29:5161. doi: 10.1016/j.coviro.2018.03.004

292. Abbink P, Larocca RA, De La Barrera RA, Bricault CA, Moseley ET, Boyd M, et al. Protective efficacy of multiple vaccine platforms against zika virus challenge in rhesus monkeys. Science. (2016) 353:112932. doi: 10.1126/science.aah6157

293. Dowd KA, Ko SY, Morabito KM, Yang ES, Pelc RS, DeMaso CR, et al. Rapid development of a DNA vaccine for zika virus. Science. (2016) 354:23740. doi: 10.1126/science.aai9137

294. Kwek SS, Watanabe S, Chan KR, Ong EZ, Tan HC, Ng WC, et al. A systematic approach to the development of a safe live attenuated zika vaccine. Nat Commun. (2018) 9:1031. doi: 10.1038/s41467-018-03337-2

295. Larocca RA, Abbink P, Peron JPS, Zanotto PMDA, Iampietro MJ, BadamchiZadeh A, et al. Vaccine protection against zika virus from Brazil. Nature. (2016) 536:474-8. doi: 10.1038/nature18952

296. Pardi N, Hogan MJ, Pelc RS, Muramatsu H, Andersen H, DeMaso CR, et al. Zika virus protection by a single low-dose nucleoside-modified mRNA vaccination. Nature. (2017) 543:248-51. doi: 10.1038/nature21428

297. Gaudinski MR, Houser KV, Morabito KM, Hu Z, Yamshchikov G, Rothwell RS, et al. Safety, tolerability, and immunogenicity of two zika virus DNA vaccine candidates in healthy adults: randomised, open-label, phase 1 clinical trials. Lancet. (2017) 6736:1-11. doi: 10.1016/S0140-6736(17) 33105-7

298. Magnani DM, Rogers TF, Maness NJ, Grubaugh ND, Beutler N, Bailey VK, et al. Fetal demise and failed antibody therapy during zika virus infection of pregnant macaques. Nat Commun. (2018) 9:1624. doi: 10.1038/s41467-018-04056-4

299. van Rompay KKA, Keesler RI, Ardeshir A, Watanabe J, Usachenko J, Singapuri A, et al. DNA vaccination before conception protects zika virus-exposed pregnant macaques against prolonged viremia and improves fetal outcomes. Sci Transl Med. (2019) 11:1-12. doi: 10.1126/scitranslmed.aay2736 
300. Bailey MJ, Broecker F, Duehr J, Arumemi F, Krammer F, Palese P, et al. Antibodies elicited by an NS1-based vaccine protect mice against zika virus. MBio. (2019) 10:e02861-18. doi: 10.1128/mBio.02861-18

301. Bailey MJ, Duehr J, Dulin H, Broecker F, Brown JA, Arumemi FO, et al. Human antibodies targeting zika virus NS1 provide protection against disease in a mouse model. Nat Commun. (2018) 9:4560. doi: 10.1038/s41467-018-07008-0

302. Nguyen SM, Antony KM, Dudley DM, Kohn S, Simmons HA, Wolfe B, et al. Highly efficient maternal-fetal Zika virus transmission in pregnant rhesus macaques. PLoS Pathog. (2017) 13:e1006378. doi: 10.1371/journal.ppat.1006378

303. Tonnerre P, Melgaço JG, Torres-Cornejo A, Pinto MA, Yue C, Blümel $\mathrm{J}$, et al. Evolution of the innate and adaptive immune response in women with acute zika virus infection. Nat Microbiol. (2020) 5:7683. doi: 10.1038/s41564-019-0618-Z

304. El Sahly HM, Gorchakov R, Lai L, Natrajan MS, Patel SM, Atmar $\mathrm{RL}$, et al. Clinical, virologic, and immunologic characteristics of zika virus infection in a cohort of US patients: prolonged RNA detection in whole blood. Open Forum Infect Dis. (2019) 6:ofy352. doi: 10.1093/ofid/ ofy 352

305. Pardy RD, Richer MJ. Protective to a T: the role of $\mathrm{T}$ cells during zika virus infection. Cells. (2019) 8:820. doi: 10.3390/cells8080820

306. Ricciardi MJ, Magnani DM, Grifoni A, Kwon Y-C, Gutman MJ, Grubaugh ND, et al. Ontogeny of the B- and T-cell response in a primary zika virus infection of a dengue-naïve individual during the 2016 outbreak in Miami, FL. PLoS Negl Trop Dis. (2017) 11:e0006000. doi: 10.1371/journal.pntd.0006000

307. Aliota MT, Dudley DM, Newman CM, Mohr EL, Gellerup DD, Breitbach ME, et al. Heterologous protection against Asian zika virus challenge in rhesus macaques. PLoS Negl Trop Dis. (2016) 10:1-22. doi: 10.1371/journal.pntd.0005168

308. Dowd KA, Demaso CR, Pelc RS, Diamond MS, Ledgerwood JE, Correspondence TCP, et al. Broadly neutralizing activity of zika virusimmune sera identifies a single viral serotype. Cell Rep. (2016) 16:148591. doi: 10.1016/j.celrep.2016.07.049

309. Bayer A, Lennemann NJ, Ouyang Y, Cherry S, Sadovsky Y, Coyne Correspondence CB, et al. Type III interferons produced by human placental trophoblasts confer protection against zika virus infection. Cell Host Microbe. (2016) 19:705-12. doi: 10.1016/j.chom.2016.03.008

310. Yockey LJ, Jurado KA, Arora N, Millet A, Rakib T, Milano KM, et al. Type I interferons instigate fetal demise after zika virus infection. Sci Immunol. (2018) 3:eaao1680. doi: 10.1126/sciimmunol.aao1680

311. Regal JF, Gilbert JS, Burwick RM. The complement system and adverse pregnancy outcomes. Mol Immunol. (2015) 67:56-70. doi: 10.1016/j.molimm.2015.02.030

312. Richani K, Soto E, Romero R, Espinoza J, Chaiworapongsa T, Nien $\mathrm{JK}$, et al. Normal pregnancy is characterized by systemic activation of the complement system. J Matern Fetal Neonatal Med. (2005) 17:23945. doi: 10.1080/14767050500072722

313. Schiela B, Bernklau S, Malekshahi Z, Deutschmann D, Koske I, Banki $Z$, et al. Active human complement reduces the zika virus load via formation of the membrane-attack complex. Front Immunol. (2018) 9:2177. doi: 10.3389/fimmu.2018.02177

314. Stettler K, Beltramello M, Espinosa DA, Graham V, Cassotta A, Bianchi $\mathrm{S}$, et al. Specificity, cross-reactivity, and function of antibodies elicited by zika virus infection. Science. (2016) 353:823-6. doi: 10.1126/science.a af8505

315. Bardina SV, Bunduc P, Tripathi S, Duehr J, Frere JJ, Brown JA, et al. Enhancement of zika virus pathogenesis by preexisting antiflavivirus immunity. Science. (2017) 356:175-80. doi: 10.1126/science.a al4365

316. Dejnirattisai W, Supasa P, Wongwiwat W, Rouvinski A, Barba-Spaeth G, Duangchinda $\mathrm{T}$, et al. Dengue virus sero-cross-reactivity drives antibodydependent enhancement of infection with zika virus. Nat Immunol. (2016) 17:1102-8. doi: 10.1038/ni.3515

317. Priyamvada L, Quicke KM, Hudson WH, Onlamoon N, Sewatanon J. Human antibody responses after dengue virus infection are highly cross-reactive to zika virus. Proc Natl Acad Sci USA. (2016) 113:78527. doi: 10.1073/pnas.1607931113

318. Gordon A, Gresh L, Ojeda S, Katzelnick LC, Sanchez N, Mercado JC, et al. Prior dengue virus infection and risk of zika: a pediatric cohort in Nicaragua. PLoS Med. (2019) 16:e1002726. doi: 10.1371/journal.pmed.1002726

319. Rodriguez-Barraquer I, Nascimento EJM, Marques ETA, Costa F, Azar $\mathrm{SR}$, Adhikarla $\mathrm{H}$, et al. Impact of preexisting dengue immunity on zika virus emergence in a dengue endemic region. Science. (2019) 363:60710. doi: $10.1126 /$ science.aav6618

320. McCracken MK, Gromowski GD, Friberg HL, Lin X, Abbink P, De La Barrera $\mathrm{R}$, et al. Impact of prior flavivirus immunity on Zika virus infection in rhesus macaques. PLoS Pathog. (2017) 13:e1006487. doi: 10.1371/journal.ppat.1006487

321. Pérez-Guzmán EX, Pantoja P, Serrano-Collazo C, Hassert MA, Ortiz-Rosa A, Rodríguez IV, et al. Time elapsed between zika and dengue virus infections affects antibody and T cell responses. Nat Commun. (2019) 10:4316. doi: 10.1038/s41467-019-12295-2

322. Singh T, Lopez CA, Giuberti C, Dennis ML, Itell HL, Heimsath $\mathrm{HJ}$, et al. Efficient transplacental IgG transfer in women infected with Zika virus during pregnancy. PLoS Negl Trop Dis. (2019) 13:e0007648. doi: 10.1371/journal.pntd. 0007648

323. Dean NE, Gsell PS, Brookmeyer R, De Gruttola V, Donnelly CA, Halloran $\mathrm{ME}$, et al. Design of vaccine efficacy trials during public health emergencies. Sci Transl Med. (2019) 11:eaat0360. doi: 10.1126/scitranslmed.aat0360

324. Rid A, Miller FG. Ethical rationale for the ebola "ring vaccination" trial design. Am J Public Health. (2016) 106:4325. doi: 10.2105/AJPH.2015.302996

Conflict of Interest: SP is serving as a consultant for vaccine programs at Merck, Pfizer, and Moderna.

The remaining authors declare that the research was conducted in the absence of any commercial or financial relationships that could be construed as a potential conflict of interest.

Copyright (c) 2020 Singh, Otero, Li, Valencia, Nelson and Permar. This is an openaccess article distributed under the terms of the Creative Commons Attribution License (CC BY). The use, distribution or reproduction in other forums is permitted, provided the original author(s) and the copyright owner(s) are credited and that the original publication in this journal is cited, in accordance with accepted academic practice. No use, distribution or reproduction is permitted which does not comply with these terms. 